Article

\title{
Fuzzy Multi-Criteria Decision-Making Approach for Online Food Delivery (OFD) Companies Evaluation and Selection: A Case Study in Vietnam
}

\author{
Ngoc Bao Tu Nguyen ${ }^{1,2, *}$, Gu-Hong Lin ${ }^{1(D)}$ and Thanh-Tuan Dang ${ }^{1, *(D)}$ \\ 1 Department of Industrial Engineering and Management, National Kaohsiung University of Science \\ and Technology, Kaohsiung 80778, Taiwan; ghlin@nkust.edu.tw \\ 2 Department of Economic and Business Administration, Da Lat University, Da Lat 67000, Vietnam \\ * Correspondence: tunnb@dlu.edu.vn (N.B.T.N.); tuandang.ise@gmail.com (T.-T.D.)
}

check for updates

Citation: Nguyen, N.B.T.; Lin, G.-H.; Dang, T.-T. Fuzzy Multi-Criteria Decision-Making Approach for Online Food Delivery (OFD)

Companies Evaluation and Selection: A Case Study in Vietnam. Processes 2021, 9, 1274. https://doi.org/ $10.3390 /$ pr9081274

Academic Editors: Jei-Zheng Wu and Chia-Yen Lee

Received: 27 June 2021

Accepted: 20 July 2021

Published: 23 July 2021

Publisher's Note: MDPI stays neutral with regard to jurisdictional claims in published maps and institutional affiliations.

Copyright: (c) 2021 by the authors. Licensee MDPI, Basel, Switzerland. This article is an open access article distributed under the terms and conditions of the Creative Commons Attribution (CC BY) license (https:/ / creativecommons.org/licenses/by/ $4.0 /)$.

\begin{abstract}
The COVID-19 pandemic has boosted the growth of the online food delivery (OFD) market in every corner of the world. In Vietnam, the food delivery service is rising rapidly and opening a large gateway of opportunities for numerous OFD platforms, also making it a competing business market in this country. Thus, to keep up with the ever-changing market dynamics, there are numerous measures and dimensions for the OFD entrepreneurs to take into consideration towards sustainable development. This paper's objective is to evaluate major OFD companies in Vietnam based on a comprehensive set of criteria, which are social and environmental criteria (healthy and safety, information security, and environmental impact), economic criteria (delivery cost, operational capability, and risk management), service quality (order fulfillment, delivery speed, convenience of payment, online/offline service level, and customer feedback), and technology (web design, real-time tracking systems, and marketing techniques). To achieve this objective, this work proposes a multi-criteria decision-making (MCDM)-based framework combining the fuzzy analytic hierarchy process (FAHP) and the weighted aggregated sum product assessment (WASPAS). The FAHP is used to generate criteria weights in which fuzzy set theory is applied to translate the linguistic evaluation statements of experts. Then, WASPAS is used to rank the OFD companies against the selected criteria. The evaluation criteria that have obtained maximum weight priority in the FAHP analysis are "convenience of payment", "delivery speed", "online service level", "order fulfillment", and "delivery cost". From the final ranking of WASPAS, Foody is today the best performing OFD player in Vietnam regarding the selected criteria, followed by GrabFood and Now. The proposed methodology can be an accurate and robust evaluation model for the industry, while the managerial implications of this study provide significant materials for decision-makers in the OFD market in improving their businesses towards sustainable development.
\end{abstract}

Keywords: online food delivery; Vietnam market; evaluation; multi-criteria decision making; fuzzy theory; FAHP; WASPAS

\section{Introduction}

Food delivery has now become an integral part of the urban lifestyle. Since the mid-2000s with the development of internet technology and the general trend towards ecommerce, increased urban living, and changing social behaviors, the online food delivery (OFD) market has been thriving [1,2], expected to reach USD 200 billion in the global output value by 2025 [3]. Online food delivery platforms give a plethora of choices and convenience along with cashback benefits, rewards, great deals, and discounts, allowing customers to order from a wide range of restaurants and doorstep delivery options with a single tap of their mobile phone. Forthwith before the ominous COVID-19 started to make headlines around the world, online food delivery was reaping the benefits of more widespread digitalization and a greater abundance of delivery apps. Without a 
doubt, the unprecedented pandemic has accelerated consumer adoption of these delivery services, with an incredible increase in new customers joining the platforms, especially in developing countries. While millions of businesses, mainly those in the aviation, tourism, and hospitality industries, were hard hit by the COVID-19 crisis and experienced a real threat of significant declines in revenue, the OFD industry has grown drastically, with the global OFD industry's turnover increasing about $140 \%$, thanks to the pandemic [4].

Food delivery services are similar to courier services in that the ordered meal is brought from the restaurant to the customer by either staff or food ordering delivery agents. This process, of course, is dependent on how a customer places his or her order. The process of ordering meals from a food cooperative or restaurant is implemented over a call, mobile apps or webpages, or through the restaurant's direct online portals, as well as their aggregator apps. Customers are frequently charged a flat delivery fee, which is sometimes waived based on purchase volume. Contactless delivery has been commonplace since the pandemic outbreak. Technological interventions have further made food delivery services prompt and quick to gain traction among consumers.

With a surge in demand, OFD has been under the spotlight as an option in Vietnam for a good number of years now. Along with many factors proliferating the growth of the market, the COVID-19 pandemic proved to be a key accelerant that has seen OFD adoption skyrocket in the country over the past year. Moreover, the existence of a robust population of millennial consumers in the country is further anticipated to boost the market expansion. Whereas Vietnam's OFD market is still in its development compared to other countries in Asia, it is exciting as increasingly more businesses have aggressively entered this field. Revenue from OFD in Vietnam stood at USD 302 million in 2020, and is expected to reach USD 557 million by 2027 [5]. Currently, the biggest players in the country's food delivery market are Grab Food and Now financed by the SEA Group, a major internet platform in Southeast Asia and Taiwan, followed by other aggressive players such as Baemin and Go Food (Indonesian decacorn Gojek). To entice merchants and customers, these companies are spending aggressively. The top ride-hailing players in Vietnam are Grab and its major competitor Gojek. Grab will invest another $\$ 500$ million in the country between 2020 and 2025, focusing on transportation, food delivery, and internet-based payments [6]. Baemin, the South Korean player funded by Woowa Brothers tech unicorn that made its debut in Vietnam in May 2019, has seen tremendous growth in terms of delivery usage in 2020 and surprisingly achieved the highest score regarding app satisfaction by brands, according to the latest survey [7].

However, with increasingly more customers opting for ordering food online, the evolving marketplace is rapidly becoming very competitive and challenging for current players in the landscape. The growth of OFD has transformed the way the OFD companies interact with customers in the presence of service quality, technology advancements, and risk factors, with significant implications for sustainability, as defined by the three pillars of economic, social, and environmental [8]. For example, from an economic perspective, OFD provides jobs and sale opportunities while being criticized for the high commissions it charges restaurants and questionable working conditions for delivery employees. From a social standpoint, OFD affects the relationship between consumers and food quality, mainly relating to public health outcomes and traffic systems. Considering the environmental dimension, the composition of alarming amounts of garbage and its substantial carbon footprints by this industry have negative consequences. Thus, in the fiercely competitive OFD market, it is essential for decision-makers and stakeholders to effectively evaluate their businesses under well-rounded aspects to ensure it is sustainable and moving forward. This assessment, therefore, can be conceptualized as a complex decision-making process with the goal of considering the dimensions' impacts on the OFD business operation in light of sustainable development.

This paper proposes a multi-criteria decision-making (MCDM)-based framework to assess the sustainable development of the OFD market in Vietnam. Initially, evaluation social and environmental dimensions (healthy and safety, information security, environ 
and mental impact) and conventional dimensions including economic (delivery cost, operational capability, and risk management), service quality (order fulfillment, delivery speed, convenience of payment, online/offline service level, and customer feedback), and technology (web design, real-time tracking systems, and marketing techniques) have been identified through literature review and expert's opinions to employ MCDM approach. Six major players in the OFD industry in Vietnam, namely, Baemin, Foody, GoFood, GrabFood, Loship, and Now, are deliberated in the assessment to demonstrate the proposed framework applicability.

The MCDM approach proposed in this study incorporates the analytic hierarchy process (AHP) using triangular fuzzy sets and the weighted aggregated sum product assessment (WASPAS). AHP is a common MCDM method used for the determination of criteria weights. Because of its features, such as ease of application and the capacity to examine benefit and cost criteria simultaneously, the AHP method is a viable approach to solving MCDM problems [9]. AHP makes weighting using pairwise comparisons easy to understand, in addition to being a method that may be readily comprehended and simplify even complex situations. Furthermore, AHP enables the decision-maker to assess the consistency of their decisions and undertake sensitivity analysis. All of these benefits make AHP more applicable than other approaches in a variety of situations. Additionally, fuzzy set theory is involved in the AHP to handle the uncertainties and vagueness that exist extensively in the experts' judgment, which are characterized by linguistic variables [10]. In this way, the ideas of the experts were turned to triangular fuzzy numbers to obtain more viable results and weights, which were then normalized, weighted, and completed the weighted normalized fuzzy decision matrix. To be able to prioritize the alternatives, WASPAS is a new approach that has recently been presented and has improved consistency and accuracy [11]. WASPAS also becomes an appropriate MCDM method for evaluating alternatives because it avoids difficult multiplication calculations and simplifies calculations. Thus, a method that is a combination of fuzzy AHP (FAHP) and WASPAS is proposed and used in this paper. The outcomes of this study could be used as a road map for the decision-makers and stakeholders in the OFD and other industries.

To the best of the authors' knowledge, there has not been carried out a thorough assessment of the OFD market in Vietnam using the proposed approach as previously outlined. In order to fill the research gaps, the following objectives are identified for the presented case study. First, the evaluation criteria in the OFD context are investigated, especially in Vietnam's market. Second, the relative weights of the OFD evaluation criteria are determined. Third, with the derived weights of criteria, OFD companies performing the best in terms of sustainable development, are suggested. Finally, the managerial implications of the proposed work are discussed. Those objectives addressed can constitute the novelty of this study. One significant advantage of this research is the comprehensive development of the OFD market evaluation criteria from the literature and consulting field experts. Moreover, this is the first study that takes the merits of the FAHP and WASPAS methodologies to evaluate the OFD market. A case study in Vietnam is discussed to present the trustworthiness of the proposed integrated framework. Additionally, the robustness of the approach is tested by performing sensitivity analysis. Finally, the managerial implications of the applied methodology and its analysis will provide insight to decisionmakers of the OFD industry not only in Vietnam, but also in the global market.

The rest part of this paper is presented as follows. Literature on previous studies in the field of the OFD industry and related sectors along with MCDM approaches is reviewed in Section 2. Materials and methods are explained in Section 3. Result analysis of the case study in Vietnam is covered in Section 4. Additionally, sensitivity analysis is conducted and presented in Section 5 to analyze the ranking results. The managerial implications and discussions are presented in Section 6, while main contributions of the research along with directions for forthcoming work are well-depicted in Section 7. 


\section{Literature Review}

\subsection{Literature Review on OFD and Relevant Criteria}

Literature in OFD and relevant sectors has focused on the study of various dimensions in the assessment process. In recent years, with the continuing vigorous development of the industry, the OFD sector and its impacts have attracted the attention of many scholars. For example, Yeo et al. [12] investigated the structure of the interaction between convenience motivation, post-usage usefulness, hedonic motivation, price-saving orientation, time-saving orientation, prior online purchase experience, consumer attitude, and behavioral intention toward OFD services. To examine the OFD market in Brazil, Pigatto et al. [1] characterized the performance of a sample of 30 companies operating in the online delivery sector in the country and analyzed the content of the websites of these companies with a view to its use as a site for conducting business transactions. In a study of e-payment systems on the OFD industry, Ghosh and Saha [13] utilized the statistical tool ANOVA to check the association between the demographic variables of the customers and online food businesses with examining the impact of the e-transaction processing system in the field. Li et al. [8] used the three pillars of sustainability as a lens to highlight the opportunities for action by all stakeholders, including OFD industry practitioners, policymakers, consumers, and academics, to maximize its positive and reduce its adverse impacts. Cheng et al. [2] integrated the key service factors for the online food delivery (OFD) industry extracted by Internet Big Data Analytics (IBDA) to construct an OFD service quality scale, aiming to effectively evaluate OFD service quality and identify the deficiencies in service quality. Gavilan et al. [14] sought to study the impact of OFD innovations on new products and services that aim to enhance the experiential value when ordering food online and the consumers' willingness to order during the COVID-19 pandemic. COVID-19-related anxiety of users was quantified and used as a moderator variable. In Table 1, the criteria considered in some recent publications for OFD and relevant sectors are listed. The table shows that some studies only considered a few key criteria, while some research has shifted to covering a more comprehensive set of criteria which led to rewarding results. In the current study, the criteria in Table 1 were presented to a panel of experts to determine their suitability to be listed as the evaluation of the OFD market in Vietnam. The panel confirmed that the set was comprehensive, covered different aspects of the assessment process, and recommended using it as the final set.

Table 1. The list of criteria used in related previous studies.

No. Authors [References]

\begin{tabular}{|c|c|c|c|c|c|c|c|c|c|c|c|c|}
\hline 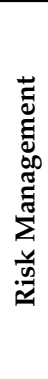 & 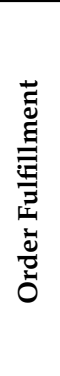 & 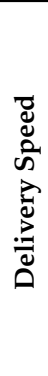 & 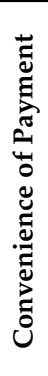 & 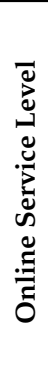 & 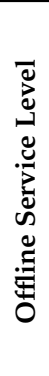 & 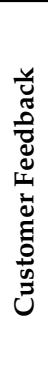 & 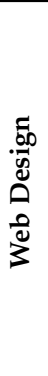 & 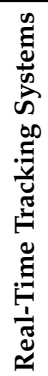 & 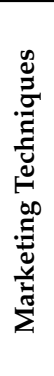 & 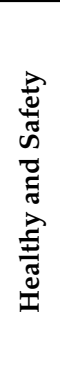 & 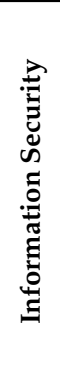 & 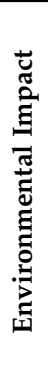 \\
\hline
\end{tabular}

\begin{tabular}{|c|c|c|c|c|c|c|c|c|c|c|c|c|c|c|c|c|}
\hline 1 & Yeo et al., (2017) [12] & $\mathrm{x}$ & & & & $\mathrm{x}$ & & $\mathrm{x}$ & $\mathrm{x}$ & & & & & & & \\
\hline 2 & Pigatto et al., (2017) [1] & & $\mathrm{x}$ & & & & & & & & $\mathrm{x}$ & & $\mathrm{x}$ & & $\mathrm{x}$ & \\
\hline 3 & Mavi et al., (2017) [15] & $x$ & & $x$ & & & & & & $x$ & & & & $x$ & & \\
\hline 4 & Ghosh and Saha (2018) [13] & $x$ & & & & $\mathrm{x}$ & $x$ & & & & $x$ & & & & $\mathrm{x}$ & \\
\hline 5 & Halaweh (2018) [16] & & & & & & $\mathrm{x}$ & $\mathrm{x}$ & & $\mathrm{x}$ & $\mathrm{x}$ & & & & $\mathrm{x}$ & \\
\hline 6 & Govindan et al., (2019) [17] & $\mathrm{x}$ & & & & & & & & & & & & $\mathrm{x}$ & & $\mathrm{x}$ \\
\hline 7 & Dospinescu et al., (2020) [18] & $x$ & & & $\mathrm{x}$ & & & & $\mathrm{x}$ & & & $x$ & & & & \\
\hline 8 & Wang (2020) [19] & & & & $x$ & & $\mathrm{x}$ & $x$ & $\mathrm{x}$ & & $x$ & & $\mathrm{x}$ & & & \\
\hline 9 & Gao et al., (2020) [20] & $x$ & & $x$ & & & & & & $\mathrm{x}$ & & & & $x$ & & $\mathrm{x}$ \\
\hline 10 & Wang et al., (2021) [21] & $\mathrm{x}$ & & $\mathrm{x}$ & & $\mathrm{x}$ & & & & $\mathrm{x}$ & & & & $\mathrm{x}$ & & $\mathrm{x}$ \\
\hline 11 & Cheng et al., (2021) [2] & & $\mathrm{x}$ & $\mathrm{x}$ & & & & & & & & $\mathrm{x}$ & & & $\mathrm{x}$ & \\
\hline 12 & Ray and Bal (2021) [22] & $x$ & & & $\mathrm{x}$ & $\mathrm{x}$ & & & $\mathrm{x}$ & $\mathrm{x}$ & & & & $\mathrm{x}$ & $\mathrm{x}$ & \\
\hline 13 & Yang et al., (2021) [23] & & $\mathrm{x}$ & & $\mathrm{x}$ & $\mathrm{x}$ & & & $\mathrm{x}$ & $\mathrm{x}$ & & & & & & $\mathrm{x}$ \\
\hline 14 & $\mathrm{Xu}(2021)$ [24] & $\mathrm{x}$ & & & $\mathrm{x}$ & $\mathrm{x}$ & & & & $\mathrm{x}$ & & & & & & \\
\hline 15 & Wang et al., (2021) [25] & $\mathrm{x}$ & $\mathrm{x}$ & $\mathrm{x}$ & & $\mathrm{x}$ & & & & $\mathrm{x}$ & & & & $\mathrm{x}$ & & $\mathrm{x}$ \\
\hline 16 & This paper & $x$ & $x$ & $x$ & $\mathrm{x}$ & $\mathrm{x}$ & $x$ & $\mathrm{x}$ & $\mathrm{x}$ & $x$ & $x$ & $x$ & $\mathrm{x}$ & $\mathrm{x}$ & $\mathrm{x}$ & $x$ \\
\hline
\end{tabular}




\subsection{Literature Review on Methodology}

The analytic hierarchy process (AHP) is proposed by Saaty in 1980 as a tool for decision making [26]. Since its appearance, it has received increasingly more attention and become one of the most used MCDM methods in the literature. Fuzziness and uncertainties are often encountered in the evaluation process due to various typical reasons, such as the complex social environment and uncertain judgments of experts [27]. When evaluating the alternatives, linguistic terms are usually adopted. To deal with vagueness in the determination of linguistic statements, many fuzzy extensions of AHP are proposed with differences in the algorithm and the degree of fuzziness involved in the analysis. For instance, Chen et al. [28] used an extended fuzzy AHP-based methodology to tackle the supplier selection problem. Triangular fuzzy numbers are utilized to describe decision makers' assessments in their study, and weight vectors are constructed based on the fuzzy synthetic extent. Priority weights are calculated as the product of each alternative's weight and the weight of the associated attribute, and alternatives are then ranked according to their priority weights. FAHP approaches also differ in terms of the fuzzy extension used in the determination of linguistic statements. The fuzzy linguistic terms can be translated into various kinds of scaling: triangular fuzzy numbers $[21,25,27,29]$, trapezoidal fuzzy sets [30,31], intuitionistic fuzzy sets [32,33], fuzzy Z-numbers [10,34], type-2 fuzzy sets $[35,36]$, and spherical fuzzy numbers [37,38], to list a few.

Zavadskas et al. [39] proposed the WASPAS method in 2012, which is one of the new multi-index MCDM techniques that has higher consistency and accuracy. Since then, the method has been adopted and employed in many areas. For example, Badalpur and Nurbakhsh [40] implemented an application of WASPAS method to identify and evaluate the risks of a road construction project in Iran. The authors also highlighted the WASPAS method as a suitable method with more accuracy among MCDM techniques for evaluating of risks in a real situation. Zavadskas et al. [41] utilized a multi-attribute assessment using WASPAS for choosing an optimal indoor environment, suggesting that the method can used for the assessment of alternatives and their evaluation according to the optimal alternative. In the literature, instead of the classic MCDM methods, a hybrid approach which consists of Fuzzy AHP-WASPAS methodologies is also applied in various study [10,42-44].

\section{Materials and Methods}

\subsection{Research Methodology}

The research methodology is generally divided into two phases, as can be seen in Figure 1. First, sustainable OFDs evaluation criteria and their description is defined (Table 2) based on the relevant literatures and expert's interview. Four main criteria are considered: economic, service quality, technology, social and environmental. Fuzzy AHP is applied to assign the preference weights of criteria based on pair wise comparison concept. The rating of each alternative and the preference weights of each criterion are presented by linguistic terms using triangular fuzzy numbers. Second, all alternatives are ranked by WASPAS model. The sensitivity analysis is performed to examine the robustness and comprehensive of the picture fuzzy decision-making approach for sustainable OFDs evaluation and selection process. 


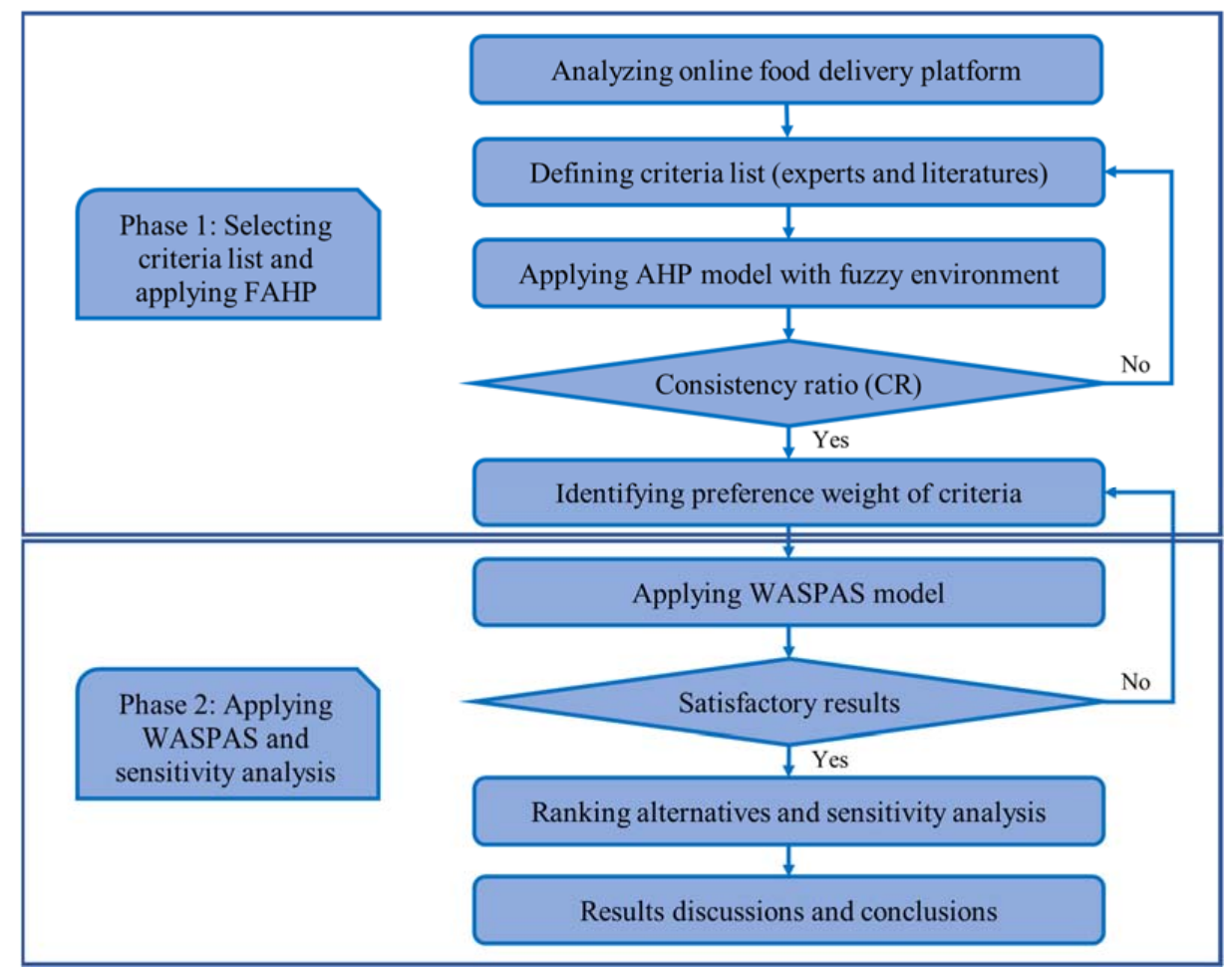

Figure 1. Research methodology for evaluation and selection OFDs.

Table 2. Sustainable OFDs evaluation criteria and their description.

\begin{tabular}{|c|c|c|c|}
\hline Main Criteria & Criteria & Goal & Description \\
\hline \multirow{3}{*}{ Economic (C1) } & C11. Delivery cost & Min & Transportation cost, labors cost, administration cost \\
\hline & C12. Operational capability & Max & Company's value propositions, operational ability expansion \\
\hline & C13. Risk management & Min & $\begin{array}{l}\text { Cash flow statement, shareholders equity, } \\
\text { investment risk management }\end{array}$ \\
\hline \multirow{6}{*}{ Service Quality (C2) } & C21. Order fulfillment & Max & $\begin{array}{l}\text { Time savings of order processing, order pick-up time, } \\
\text { cleanliness of packaged food }\end{array}$ \\
\hline & C22. Delivery speed & Min & Timeliness of order arrival \\
\hline & C23. Convenience of payment & Max & Diversity of payment methods \\
\hline & C24. Online service level & Max & Timeliness of SMS, response speed of customer service staff \\
\hline & C25. Offline service level & Max & $\begin{array}{l}\text { Attitude of delivery staff, dealers' handling of } \\
\text { customer complaints }\end{array}$ \\
\hline & C26. Customer feedback & Max & Online reviews, online rating, customer behavioral intention \\
\hline \multirow{3}{*}{ Technology (C3) } & C31. Web design & Max & Update-to-date platform, page visual effects, user-friendly \\
\hline & $\begin{array}{l}\text { C32. Real-time } \\
\text { tracking systems }\end{array}$ & Max & Online tracking, smart technology for tracking and tracing \\
\hline & C33. Marketing techniques & Max & $\begin{array}{l}\text { Digital marketing, digital technologies for } \\
\text { product advertising efforts }\end{array}$ \\
\hline \multirow{3}{*}{$\begin{array}{l}\text { Social and } \\
\text { environmental }(\mathrm{C} 4)\end{array}$} & C41. Healthy and safety & Max & Food hygiene, contactless delivery, health and safety guidelines \\
\hline & C42. Information security & Max & Customer's data protection, security of online payment \\
\hline & C43. Environmental impact & Min & Exhaust carbon emissions, solid waste, traffic noise \\
\hline
\end{tabular}




\subsection{Fuzzy Analytical Hierarchy Process (FAHP)}

Zadeh [45] introduced the fuzzy set theory to handle uncertain conditions in multicriteria decision-making problems. As shown in Figure 2 and Equation (1), a triangular fuzzy number (TFN) is defined as $(a, b, c)$, which indicate the lower value, mean value and upper value, respectively.

$$
\mu(x / \widetilde{F})=\left\{\begin{array}{cl}
(x-a) /(b-a), & a \leq x \leq b \\
(c-x) /(c-b), & b \leq x \leq c \\
0, & \text { otherwise }
\end{array}\right.
$$

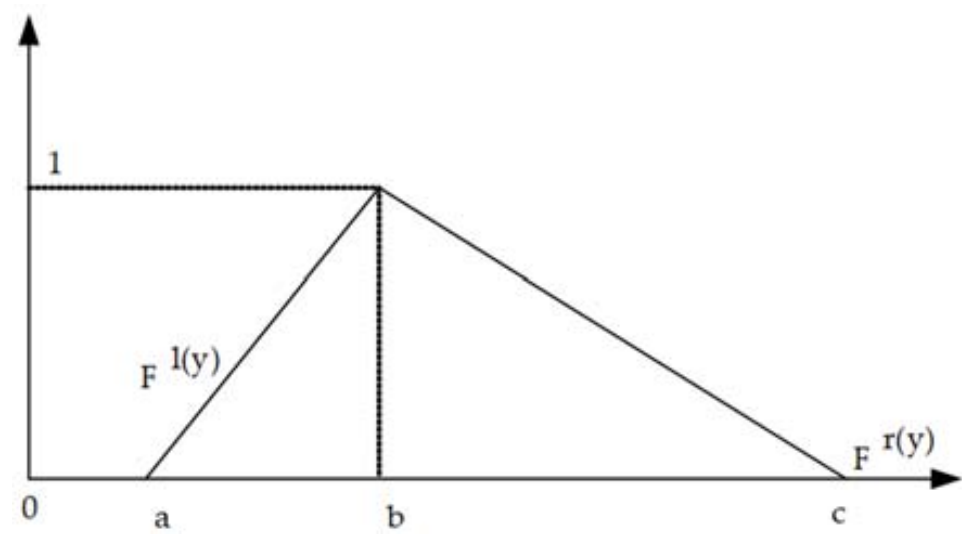

Figure 2. The membership function of TFN.

The membership function of triangular fuzzy number is shown in Equation (2).

$$
\widetilde{F}=\left(F^{l(y)}, F^{r(y)}\right)=[a+(b-a) y, c+(b-c) y], y \in[0,1]
$$

where $F^{l(y)}, F^{r(y)}$ are two sides of the fuzzy number.

FAHP is an extension of AHP to solve the uncertain MCDM problems. TFN is one of the useful models in fuzzy theory. The procedure of fuzzy analytical hierarchy process (FAHP) is shown as follows [46].

Step 1: Conduct the pairwise comparison matrices $\widetilde{M}$ for all criteria. This matrix is an $n \times n$ real matrix, where $n$ is the number of criteria. Each of element of matrix $\widetilde{M}\left(\widetilde{l_{i j}}\right)$ denotes the importance of the $i^{\text {th }}$ criterion over the $j^{\text {th }}$ criterion. The relative importance between two criteria is measured according to the numerical scale of $\widetilde{1}-\widetilde{9}$ by assigned linguistic variables (i.e., triangular fuzzy number (TFN)). A tilde symbol $(\sim)$ is placed above the parameter symbols to indicate imprecise data including the pessimistic, most likely and optimistic values. The fuzzy triangle scale and assigned by TFN used in FAHP are shown in Table 3, as follows.

Table 3. Linguistic terms in FAHP model.

\begin{tabular}{ccc}
\hline Scale & Definition & Fuzzy Triangle Scale \\
\hline$\widetilde{1}$ & Equal importance & $(1,1,1)$ \\
$\widetilde{2}$ & Weak importance & $(1,2,3)$ \\
$\widetilde{3}$ & Not bad & $(2,3,4)$ \\
$\widetilde{4}$ & Preferable & $(3,4,5)$ \\
$\widetilde{5}$ & Importance & $(4,5,6)$ \\
$\widetilde{6}$ & Fairly importance & $(5,6,7)$ \\
$\widetilde{7}$ & Very important & $(6,7,8)$ \\
$\widetilde{8}$ & Absolute & $(7,8,9)$ \\
$\widetilde{9}$ & Perfect & $(8,9,10)$ \\
\hline
\end{tabular}


Suppose that a decision group consists of $K$ experts. The geometrical mean is used to create an aggregated fuzzy pairwise comparison matrix, as can be seen in Equation (3).

$$
\widetilde{M}=\left(\begin{array}{cccc}
1 & \widetilde{l_{12}} & \cdots & \widetilde{l_{1 n}} \\
\widetilde{l_{21}} & 1 & \cdots & \widetilde{l_{2 n}} \\
\cdots & \cdots & \cdots & \cdots \\
\widetilde{l_{n 1}} & \widetilde{l_{n 2}} & \cdots & 1
\end{array}\right)=\left(\begin{array}{cccc}
1 & \widetilde{l_{12}} & \cdots & \widetilde{l_{1 n}} \\
1 / \widetilde{l_{12}} & 1 & \cdots & \widetilde{l_{2 n}} \\
\cdots & \cdots & \cdots & \cdots \\
1 / \widetilde{l_{1 n}} & 1 / \widetilde{l_{2 n}} & \cdots & 1
\end{array}\right)
$$

where $\widetilde{l_{i j}}=\left\{\begin{array}{c}\widetilde{9}^{-1}, \widetilde{8}^{-1}, \widetilde{7}^{-1}, \widetilde{6}^{-1}, \widetilde{5}^{-1}, \widetilde{4}^{-1}, \widetilde{3}^{-1}, \widetilde{2}^{-1}, \widetilde{1}^{-1}, \widetilde{1}, \widetilde{2}, \widetilde{3}, \widetilde{4}, \widetilde{5}, \widetilde{6}, \widetilde{7}, \widetilde{8}, \widetilde{9} \text { such that } i \neq j \\ 1 \text { such that } i=j\end{array}\right.$

Step 2: Use the fuzzy geometrical mean technique to define the fuzzy geometrical mean of each criterion, which is calculated by Equation (4).

$$
\widetilde{r_{i}}=\left(\prod_{j=1}^{n} \widetilde{l_{i j}}\right)^{1 / n} \text { such that } i=1,2, \ldots, n
$$

where $\widetilde{r_{i}}$ is the fuzzy geometrical mean and $\widetilde{l_{i j}}$ is the fuzzy comparison value from group of decision-maker with respect to the $i^{\text {th }}$ dimension over the $j^{\text {th }}$ criterion.

Step 3: Define the fuzzy preference weights of each criterion, which is calculated by Equation (5).

$$
\widetilde{w}_{i}=\widetilde{r}_{i}(\times)\left(\widetilde{r_{1}}(+) \widetilde{r_{2}}(+) \ldots(+) \widetilde{r_{n}}\right)^{-1}
$$

Step 4: Calculate the average weight criteria, also known as defuzzify the fuzzy preference weights by using the average weight criteria $G_{i}$, which is shown in Equation (6).

$$
G_{i}=\frac{\widetilde{w_{1}}(+) \widetilde{w_{2}}(+) \ldots(+) \widetilde{w_{n}}}{n}
$$

Step 5: Calculate the normalized preference weight of each criterion $H_{i}$, which is presented in Equation (7).

$$
H_{i}=\frac{G_{i}}{\sum_{i=1}^{n} G_{i}}
$$

\subsection{Weighted Aggregated Sum Product Assessment (WASPAS)}

The weighted aggregated sum product assessment (WASPAS) is well known as a robust and comprehensive MCDM technique based on an aggregating weighted sum model (WSM) and weighted product model (WPM). This method evaluates alternatives by considering the weighted aggregation of the additive and multiplicative aspect, which reflects more realistic problems. WASPAS is notable for its efficiency and mathematical simplicity, as well as the fact that it produces more accurate results than the WSM and WPM approaches. The stage of WASPAS is described based on the following steps [47].

Step 1: Develop the decision matrices as the performance rating for all alternative based on each criterion and determine the preference weights of each criterion. In WASPAS model, the preference weights of each criterion are obtained from FAHP model.

Step 2: Normalize decision matrix for benefit and cost criteria using Equations (8)-(10), respectively. Note that where $x_{i j}$ denotes the performance rating of $m$ alternative $A_{i}$ with respect to $n$ criteria $C_{j}$ by $k^{\text {th }}$ expert.

$$
\begin{gathered}
x_{i j}=\frac{1}{k}\left(x_{i j}^{1}+x_{i j}^{2}+\ldots+x_{i j}^{k}\right) \\
s_{i j}=\frac{x_{i j}}{\max _{i} x_{i j}} \text { such that } i=1,2, \ldots, m ; j=1,2, \ldots, n
\end{gathered}
$$




$$
s_{i j}=\frac{x_{i j}}{\min _{i} x_{i j}} \text { such that } i=1,2, \ldots, m ; j=1,2, \ldots, n
$$

Step 3: Calculate the relative weighted $\left(w_{j}\right)$ normalized decision matrix for weighted sum model (WSM) using Equation (11).

$$
Q_{i}=\sum_{j=1}^{n} s_{i j} w_{j} \text { such that } i=1,2, \ldots, m
$$

Step 4: Calculate the relative weighted $\left(w_{j}\right)$ normalized decision matrix for weighted product model (WPM) using Equation (12).

$$
P_{i}=\prod_{j=1}^{n}\left(s_{i j}\right)^{w_{j}} \text { such that } i=1,2, \ldots, m
$$

Step 5: Calculate the integrated utility function value of WASPAS using Equation (13) as follows.

$$
K_{i}=\lambda Q_{i}+(1-\lambda) P_{i}=\lambda \sum_{j=1}^{n} s_{i j} w_{j}+(1-\lambda) \prod_{j=1}^{n}\left(s_{i j}\right)^{w_{j}} \text { such that } \lambda \in[0,1]
$$

The value of $\lambda$ (i.e., coefficient value of WASPAS or trade-off parameter) is defined based on the assumption that the total of all alternatives WSM scores must be equal to the total of WPM score, as can be seen in Equation (14).

$$
\lambda=\frac{\sum_{i=1}^{m} P_{i}}{\sum_{i=1}^{m} Q_{i}+\sum_{i=1}^{m} P_{i}}
$$

It is proposed to measure the accuracy of the WASPAS model based on initial criteria accuracy. When $\lambda=0$, WASPAS is transformed to WPM, and when $\lambda=1$, WASPAS is transformed to WSM.

In this paper, the value of $\lambda$ is considered as $0.5(\lambda=0.5)$ for beginning analysis (base case). Based on the ranking of preference order, the optimal alternative is the highest value of the utility function $K_{i}$.

\section{Result Analysis}

\subsection{A Case Study in Vietnam}

In this paper, a case study of online food delivery (OFD) platform companies in Vietnam is used to test the proposed model's effectiveness. After preliminary assessment, a total of six experts helped to do survey questionnaires to rank the top six OFDs companies (Baemin, Foody, GoFood, GrabFood, Loship, and Now) who all have more than ten years of work experience in the online food delivery industry. To this end, FAHP is used to determine the relative preference weight of each criterion. Figure 3 presents the decision hierarchy for evaluation and selection OFDs including four main criteria and 15 criteria, which are economic (delivery cost, operational capabilities, and risk management), service quality (order fulfillment, delivery speed, convenience of payment, online service level, offline service level, and customer feedback), technological (web design, realtime tracking systems, and marketing techniques), and social and environmental (healthy and safety, information security, and environmental impact). Then, WASPAS is used to rank all alternatives, and the robustness and comprehensive of the model is proven using sensitivity analysis. 


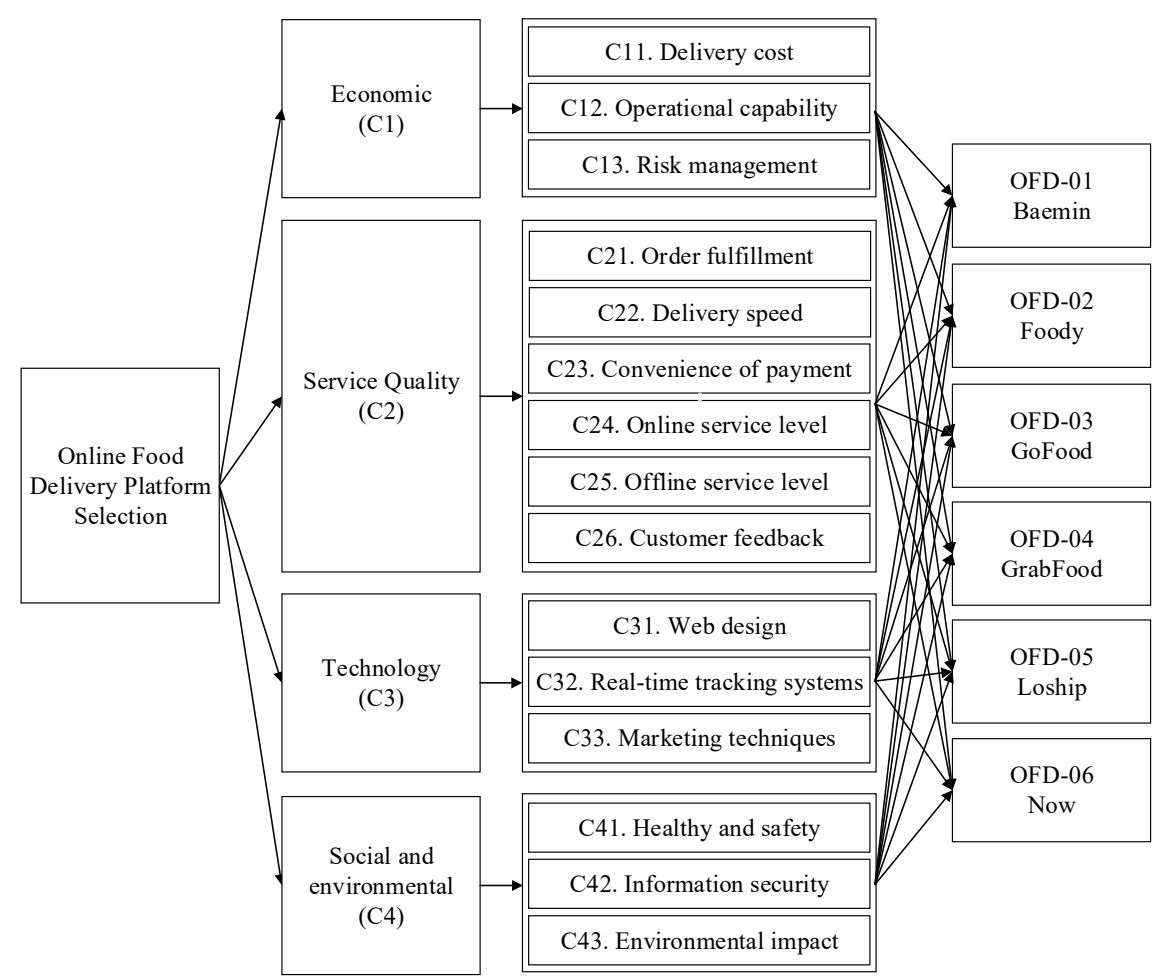

Figure 3. The decision hierarchy for evaluation and selection OFDs.

\subsection{Result of Fuzzy AHP Model}

In FAHP, the checking of consistency ratio significant affect the result, an example of the calculation of the four main criteria is shown in the following FAHP procedure. The team of experts conduct initial assessments for rating the performance of these criteria, consisting of economic (C1), service quality (C2), technology (C3), and social and environmental (C4). The initial comparison matrix and the aggregated fuzzy comparison matrix of FAHP model are presented in Tables 4 and 5, respectively.

Table 4. The initial comparison matrix of FAHP model.

\begin{tabular}{|c|c|c|c|c|c|c|c|c|c|c|c|c|c|c|c|c|c|c|}
\hline \multirow{2}{*}{ 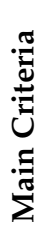 } & \multicolumn{17}{|c|}{ Triangular Fuzzy Scale } & \multirow{2}{*}{ 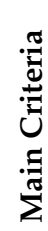 } \\
\hline & $\begin{array}{l}0 \\
\text { ㄱ. } \\
\text { aे } \\
\infty\end{array}$ & 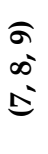 & $\begin{array}{l}\infty \\
\stackrel{\infty}{0} \\
0\end{array}$ & $\begin{array}{l}\tilde{5} \\
0 \\
0\end{array}$ & $\begin{array}{l}6 \\
10 \\
+\end{array}$ & \begin{tabular}{l} 
Dn \\
\multirow{-}{*}{} \\
$\dot{0}$
\end{tabular} & 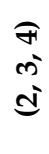 & 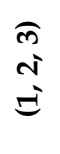 & $\begin{array}{l}I \\
\Xi \\
ت\end{array}$ & $\begin{array}{l}\text { m } \\
\text { N } \\
=\end{array}$ & $\begin{array}{l}\text { f } \\
\text { ले } \\
\stackrel{1}{ }\end{array}$ & 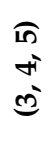 & $\begin{array}{l}6 \\
10 \\
+\end{array}$ & 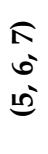 & $\begin{array}{l}\infty \\
\hat{0} \\
0\end{array}$ & 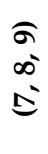 & $\begin{array}{l}\hat{0} \\
\text { aे } \\
\text { के }\end{array}$ & \\
\hline C1 & & & & & & & & & & $x$ & & & & & & & & $\mathrm{C} 2$ \\
\hline C1 & & & & & & & & $x$ & & & & & & & & & & C3 \\
\hline $\mathrm{C} 1$ & & & & & & & & $x$ & & & & & & & & & & $\mathrm{C} 4$ \\
\hline $\mathrm{C} 2$ & & & & & & & $x$ & & & & & & & & & & & C3 \\
\hline $\mathrm{C} 2$ & & & & & $x$ & & & & & & & & & & & & & C4 \\
\hline C3 & & & & & & $x$ & & & & & & & & & & & & C4 \\
\hline
\end{tabular}

Table 5. The aggregated fuzzy comparison matrix of FAHP model.

\begin{tabular}{ccccc}
\hline Criteria & Economic (C1) & Service Quality (C2) & Technology (C3) & Social and Environmental (C4) \\
\hline Economic (C1) & $(1,1,1)$ & $(1 / 3,1 / 2,1)$ & $(1,2,3)$ & $(1,2,3)$ \\
Service Quality (C2) & $(1,2,3)$ & $(1,1,1)$ & $(2,3,4)$ & $(4,5,6)$ \\
Technology (C3) & $(1 / 3,1 / 2,1)$ & $(1 / 4,1 / 3,1 / 2)$ & $(1,1,1)$ & $(3,4,5)$ \\
Social and & $(1 / 3,1 / 2,1)$ & $(1 / 6,1 / 5,1 / 4)$ & $(1 / 5,1 / 4,1 / 3)$ & $(1,1,1)$ \\
environmental (C4) & & & \\
\hline
\end{tabular}


The linguistics terms (i.e., triangular fuzzy number) are transferred to the crisp value using pessimistic value (lower bound) and optimistic value (upper bound) of the fuzzy comparison matrix to check the consistency ratio $(C R)$ of the performance evaluation score $[48,49]$. The non-fuzzy comparison matrix of the main criteria is presented in Table 6 .

Table 6. The non-fuzzy comparison matrix of FAHP model.

\begin{tabular}{ccccc}
\hline Criteria & Economic (C1) & Service Quality (C2) & Technology (C3) & Social and Environmental (C4) \\
\hline Economic (C1) & 1.0000 & 0.5774 & 1.7321 & 1.7321 \\
Service Quality (C2) & 1.7321 & 1.0000 & 2.8284 & 4.8990 \\
Technology (C3) & 0.5774 & 0.3536 & 1.0000 & 3.8730 \\
$\quad$ Social and & 0.5774 & 0.2041 & 0.2582 & 1.0000 \\
environmental (C4) & & & 5.8187 & 11.5040 \\
\hline Sum & 3.8868 & 2.1350 & & \\
\hline
\end{tabular}

The normalized pairwise comparison matrix is generated by dividing each value in a column of the matrix by its column sum to obtain the priority vector of the four main criteria of the FAHP model. As shown in Table 7, the priority vector is then determined by averaging the row entries in the normalized matrix.

Table 7. The normalized comparison matrix of FAHP model.

\begin{tabular}{cccccc}
\hline Criteria & Economic (C1) & Service Quality (C2) & Technology (C3) & Social and Environmental (C4) & Priority Vector \\
\hline Economic (C1) & 0.2573 & 0.2704 & 0.2977 & 0.1506 & 0.2440 \\
Service Quality (C2) & 0.4456 & 0.4684 & 0.4861 & 0.4258 & 0.4565 \\
Technology (C3) & 0.1485 & 0.1656 & 0.1719 & 0.0869 & 0.2057 \\
Social and & 0.1485 & 0.0956 & 0.0444 & 1.0000 & 0.0939 \\
environmental (C4) & & 1.0000 & 1.0000 & & 1.0000 \\
\hline Sum & 1.0000 & & &
\end{tabular}

The largest eigenvector $\left(\lambda_{\max }\right)$ is calculated to determine the consistency index $(C I)$, the random index $(R I)$, and the consistency ratio $(C R)$, as below.

$$
\begin{gathered}
{\left[\begin{array}{llll}
0.2573 & 0.2704 & 0.2977 & 0.1506 \\
0.4456 & 0.4684 & 0.4861 & 0.4258 \\
0.1485 & 0.1656 & 0.1719 & 0.3367 \\
0.1485 & 0.0956 & 0.0444 & 0.0869
\end{array}\right] \times\left[\begin{array}{l}
0.2440 \\
0.4565 \\
0.2057 \\
0.0939
\end{array}\right]=\left[\begin{array}{l}
1.0263 \\
1.9206 \\
0.8715 \\
0.3810
\end{array}\right]} \\
{\left[\begin{array}{l}
1.0263 \\
1.9206 \\
0.8715 \\
0.3810
\end{array}\right] /\left[\begin{array}{l}
0.2440 \\
0.4565 \\
0.2057 \\
0.0939
\end{array}\right]=\left[\begin{array}{l}
4.2066 \\
4.2074 \\
4.2372 \\
4.0592
\end{array}\right]}
\end{gathered}
$$

In this paper, a total of four main criteria is considered. Therefore, we get $n=4$. Consequently, $\lambda_{\max }$ and $C I$ are computed as below.

$$
\begin{gathered}
\lambda_{\max }=\frac{4.2066+4.2074+4.2372+4.0592}{4}=4.1776 \\
C I=\frac{\lambda_{\max }-n}{n-1}=\frac{4.1776-4}{4-1}=0.0592
\end{gathered}
$$

such that $n=4$, we get $R I=0.9$, and the consistency ratio $(C R)$ is computed as follows.

$$
C R=\frac{C I}{R I}=\frac{0.0592}{0.9}=0.0658
$$

According to the result, $C R=0.0658<0.1$. Therefore, the pairwise comparison matrix is totally consistent, and the result of FAHP model is satisfactory. Subsequently, other 
criteria are calculated using the same procedure. The aggregated fuzzy comparison matrix all criteria is shown in Table A1 (Appendix A).

The assessment of each criterion for alternatives in this study is described by linguistic phrases in triangular fuzzy numbers, which include pessimistic, most likely, and optimistic values. As shown in Table 8, the fuzzy geometric mean idea is used to generate the relative significant preference weights of all criteria. According to the results, the fuzzy weight of criteria delivery cost (C11), has the lowest weight (pessimistic value) at 0.0344 , the middle weight (most likely value) of 0.0781 , and the highest weight (optimistic value) of 0.1769 . As the same concept, the fuzzy weight of criteria operational capability (C12), has the pessimistic weight at 0.0280 , the most likely weight of 0.0621 , and the most optimistic weight of 0.1404 . Other criteria have the same clarification. These fuzzy preference weights will be defuzzied into script value by using the average weight criteria. Then, they are normalized into relative preference weight and used in WASPAS model for ranking alternatives in the next phase.

Table 8. The fuzzy weights and their normalization of each criterion of FAHP model.

\begin{tabular}{|c|c|c|c|c|c|c|c|c|}
\hline \multirow{2}{*}{$\begin{array}{c}\text { Criteria } \\
\text { C11. Delivery cost }\end{array}$} & \multirow{2}{*}{$\begin{array}{c}\text { Goal } \\
\text { Min }\end{array}$} & \multicolumn{3}{|c|}{ Fuzzy Geometric Mean } & \multicolumn{3}{|c|}{ Fuzzy Weights } & \multirow{2}{*}{$\frac{\text { Normalization }}{0.0800}$} \\
\hline & & 0.7920 & 1.2297 & 1.8932 & 0.0344 & 0.0781 & 0.1769 & \\
\hline C12. Operational capability & Max & 0.6454 & 0.9766 & 1.5034 & 0.0280 & 0.0621 & 0.1404 & 0.0637 \\
\hline C13. Risk management & Min & 0.5685 & 0.8381 & 1.2901 & 0.0247 & 0.0533 & 0.1205 & 0.0549 \\
\hline C21. Order fulfillment & Max & 0.7641 & 1.2125 & 1.8370 & 0.0332 & 0.0770 & 0.1716 & 0.0779 \\
\hline C22. Delivery speed & Min & 0.9160 & 1.3416 & 1.9637 & 0.0398 & 0.0852 & 0.1834 & 0.0853 \\
\hline C23. Convenience of payment & Max & 1.4431 & 1.9808 & 2.6880 & 0.0626 & 0.1259 & 0.2511 & 0.1215 \\
\hline C24. Online service level & Max & 0.9173 & 1.3387 & 1.9249 & 0.0398 & 0.0851 & 0.1798 & 0.0842 \\
\hline C25. Offline service level & Max & 0.6898 & 1.0433 & 1.4904 & 0.0299 & 0.0663 & 0.1392 & 0.0651 \\
\hline C26. Customer feedback & Max & 0.6213 & 0.9235 & 1.3371 & 0.0270 & 0.0587 & 0.1249 & 0.0582 \\
\hline C31. Web design & Max & 0.7407 & 1.0483 & 1.4737 & 0.0321 & 0.0666 & 0.1377 & 0.0654 \\
\hline C32. Real-time tracking systems & Max & 0.4381 & 0.6197 & 0.9380 & 0.0190 & 0.0394 & 0.0876 & 0.0404 \\
\hline C33. Marketing techniques & Max & 0.7271 & 1.0930 & 1.5798 & 0.0316 & 0.0695 & 0.1476 & 0.0687 \\
\hline C41. Healthy and safety & Max & 0.4705 & 0.6854 & 1.0287 & 0.0204 & 0.0435 & 0.0961 & 0.0443 \\
\hline C42. Information security & Max & 0.4476 & 0.6450 & 0.9629 & 0.0194 & 0.0410 & 0.0900 & 0.0416 \\
\hline C43. Environmental impact & Min & 0.5231 & 0.7615 & 1.1285 & 0.0227 & 0.0484 & 0.1054 & 0.0488 \\
\hline
\end{tabular}

Figure 4 depicts the FAHP model's significance level of criteria. As shown, convenience of payment (C23), delivery speed (C22), online service level (C24), delivery cost (C11), and order fulfillment (C21) are the top five significant criteria, scored at 0.1465 , $0.1028,0.1016,0.0965$, and 0.0939 , respectively. The findings suggest that, in the evaluation of experts, service quality (i.e., convenience of payment, delivery speed, online service level, and order fulfillment) should be paid greater attention than the other aspects.

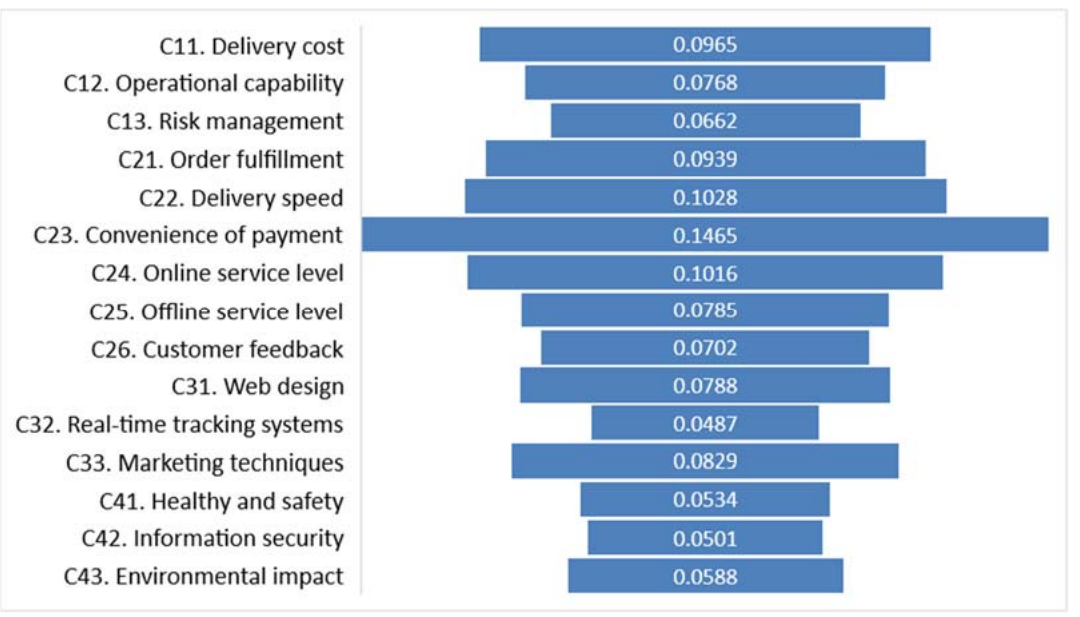

Figure 4. The relative preference weight of criteria of FAHP model. 


\subsection{Result of WASPAS Model}

In WASPAS model, a triangular fuzzy number is used to describe the performance rating of each alternative (Baemin, Foody, GoFood, GrabFood, Loship, Now). Besides, the relative preference weight of each criterion is calculated from the FAHP model. WASPAS model choose the optimal alternative by considering the weighted aggregation of the additive and multiplicative method, which evaluate and rank the alternatives with the high order of reliability. The weighted normalized matrix for WSM and the exponentially weighted normalized matrix for WPM are presented in Tables 9 and 10, respectively.

Table 9. The weighted normalized matrix for WSM (WASPAS model).

\begin{tabular}{cccccccccc}
\hline OFDS & Alternatives & $\mathbf{C 1 1}$ & $\mathbf{C 1 2}$ & $\mathbf{C 1 3}$ & $\mathbf{C 2 1}$ & $\mathbf{C 2 2}$ & C23 & C24 & C25 \\
\hline OFD-01 & Baemin & 0.0356 & 0.0306 & 0.0200 & 0.0240 & 0.0533 & 0.0456 & 0.0371 & 0.0300 \\
OFD-02 & Foody & 0.0200 & 0.0382 & 0.0129 & 0.0779 & 0.0164 & 0.1215 & 0.0842 & 0.0651 \\
OFD-03 & GoFood & 0.0457 & 0.0178 & 0.0314 & 0.0210 & 0.0355 & 0.0557 & 0.0371 & 0.0300 \\
OFD-04 & GrabFood & 0.0133 & 0.0637 & 0.0088 & 0.0599 & 0.0213 & 0.1013 & 0.0573 & 0.0476 \\
OFD-05 & Loship & 0.0800 & 0.0102 & 0.0549 & 0.0150 & 0.0853 & 0.0203 & 0.0101 & 0.0150 \\
OFD-06 & Now & 0.0188 & 0.0408 & 0.0122 & 0.0479 & 0.0237 & 0.0912 & 0.0607 & 0.0451 \\
\hline OFDS & Alternatives & $\mathbf{C 2 6}$ & $\mathbf{C 3 1}$ & $\mathbf{C 3 2}$ & $\mathbf{C 3 3}$ & $\mathbf{C 4 1}$ & $\mathbf{C 4 2}$ & $\mathbf{C 4 3}$ \\
\hline OFD-01 & Baemin & 0.0233 & 0.0178 & 0.0158 & 0.0317 & 0.0119 & 0.0144 & 0.0244 \\
OFD-02 & Foody & 0.0582 & 0.0654 & 0.0404 & 0.0687 & 0.0443 & 0.0416 & 0.0081 \\
OFD-03 & GoFood & 0.0256 & 0.0357 & 0.0281 & 0.0502 & 0.0255 & 0.0240 & 0.0130 \\
OFD-04 & GrabFood & 0.0466 & 0.0594 & 0.0369 & 0.0608 & 0.0340 & 0.0336 & 0.0085 \\
OFD-05 & Loship & 0.0116 & 0.0119 & 0.0070 & 0.0106 & 0.0119 & 0.0080 & 0.0488 \\
OFD-06 & Now & 0.0466 & 0.0505 & 0.0298 & 0.0397 & 0.0255 & 0.0272 & 0.0093 \\
\hline
\end{tabular}

Table 10. The exponentially weighted normalized matrix for WPM (WASPAS model).

\begin{tabular}{cccccccccc}
\hline OFDS & Alternatives & C11 & C12 & C13 & C21 & C22 & C23 & C24 & C25 \\
\hline OFD-01 & Baemin & 0.9372 & 0.9543 & 0.9460 & 0.9123 & 0.9607 & 0.8876 & 0.9332 & 0.9509 \\
OFD-02 & Foody & 0.8950 & 0.9680 & 0.9237 & 1.0000 & 0.8688 & 1.0000 & 1.0000 & 1.0000 \\
OFD-03 & GoFood & 0.9562 & 0.9221 & 0.9698 & 0.9028 & 0.9281 & 0.9095 & 0.9332 & 0.9509 \\
OFD-04 & GrabFood & 0.8664 & 1.0000 & 0.9043 & 0.9798 & 0.8885 & 0.9781 & 0.9680 & 0.9798 \\
OFD-05 & Loship & 1.0000 & 0.8898 & 1.0000 & 0.8794 & 1.0000 & 0.8043 & 0.8364 & 0.9090 \\
OFD-06 & Now & 0.8907 & 0.9720 & 0.9208 & 0.9629 & 0.8965 & 0.9656 & 0.9727 & 0.9763 \\
\hline OFDS & Alternatives & $\mathbf{C 2 6}$ & $\mathbf{C 3 1}$ & $\mathbf{C 3 2}$ & $\mathbf{C 3 3}$ & $\mathbf{C 4 1}$ & $\mathbf{C 4 2}$ & $\mathbf{C 4 3}$ & 0.9667 \\
OFD-01 & Baemin & 0.9481 & 0.9186 & 0.9628 & 0.9482 & 0.9436 & 0.9569 & 0.9163 \\
OFD-02 & Foody & 1.0000 & 1.0000 & 1.0000 & 1.0000 & 1.0000 & 1.0000 & 0.9375 \\
OFD-03 & GoFood & 0.9533 & 0.9612 & 0.9855 & 0.9787 & 0.9760 & 0.9774 & 0.9182 \\
OFD-04 & GrabFood & 0.9871 & 0.9938 & 0.9963 & 0.9916 & 0.9885 & 0.9912 & 1.0000 \\
OFD-05 & Loship & 0.9106 & 0.8946 & 0.9318 & 0.8793 & 0.9436 & 0.9338 & 0.9223 \\
\hline
\end{tabular}

According to the process of WASPAS model, the aggregated utility function value $K_{i}$ is calculated using weighted sum mode $l Q_{i}(\mathrm{WSM})$ and weighted product model $P_{i}$ (WSM), as can be seen in Table 11. From the results, the top three online food delivery (OFD) platform companies are Foody (OFD-02), GrabFood (OFD-04), and Now (OFD-06) ranked the first, second, and third with scores of 0.7000, 0.6023, and 0.5421, respectively. The final ranking order of all alternatives from WASPAS model is visualized in Figure 5. 
Table 11. The aggregated utility function value of WASPAS model.

\begin{tabular}{cccccc}
\hline OFDS & Alternatives & $\boldsymbol{Q}_{\boldsymbol{i}}$ & $\boldsymbol{P}_{\boldsymbol{i}}$ & $\boldsymbol{K}_{\boldsymbol{i}}$ & Ranking Order \\
\hline OFD-01 & Baemin & 0.4154 & 0.4053 & 0.4104 & 5 \\
OFD-02 & Foody & 0.7630 & 0.6371 & 0.7000 & 1 \\
OFD-03 & GoFood & 0.4764 & 0.4570 & 0.4667 & 4 \\
OFD-04 & GrabFood & 0.6530 & 0.5517 & 0.6023 & 2 \\
OFD-05 & Loship & 0.4006 & 0.2814 & 0.3410 & 6 \\
OFD-06 & Now & 0.5689 & 0.5152 & 0.5421 & 3 \\
\hline
\end{tabular}

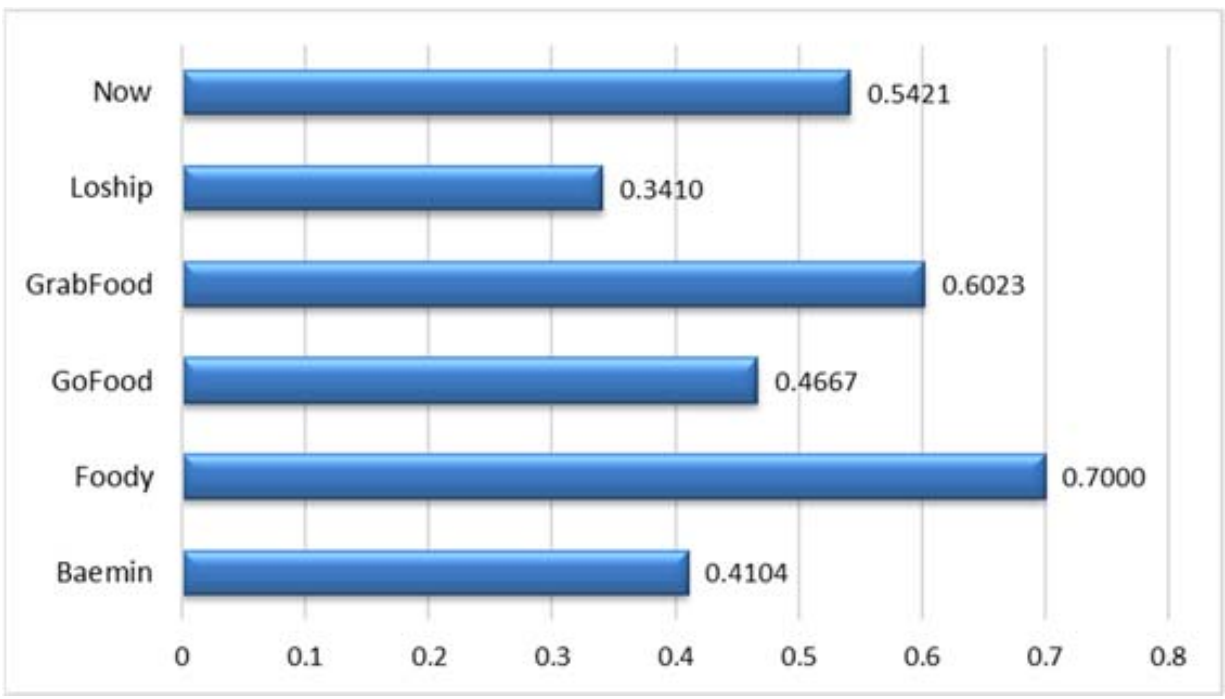

Figure 5. Final ranking order of WASPAS model.

\section{Sensitivity Analysis}

In this paper, the value of $\lambda$ is considered as $0.5(\lambda=0.5)$ for beginning analysis (base case). Following thar, a sensitivity analysis is performed to demonstrate the suggested methodology's reliability and applicability. In the sensitivity analysis, the proposed methodology's outcomes are discussed by changing the range of coefficient value $(\lambda)$ from 0 to 1 , which can change the results as expected. It shows the robustness and comprehensive of the picture fuzzy decision-making approach for sustainable OFDs evaluation and selection process.

The final appraisal scores and the final ranking of alternatives based on sensitivity analysis of WASPAS model are shown in Table 12 and Figure 6, respectively. From the results, it shows that the best alternative is always the same when changing the values of coefficient value $(\lambda)$ from 0 to 1 . It can be concluded that Foody (OFD-02) is consistently the optimal alternative to take over. Besides, GrabFood (OFD-04) and Now (OFD-06) are also ranked the second and third positions, which is also better alternatives among candidates. As a result, it can be said that the applicability of the suggested model to real-world problems has been established. The sensitivity analysis is performed to investigate the reliability of the proposed picture fuzzy decision-making approach. The study successfully proposed a hybrid MCDM model by combining FAHP and WASPAS to support the evaluation and selection of sustainable online food delivery (OFD) platform companies. 
Table 12. The final appraisal scores of WASPAS model.

\begin{tabular}{ccccccccccccc}
\hline \multirow{2}{*}{ Alternatives } & \multicolumn{10}{c}{ Coefficient Values $(\boldsymbol{\lambda})$} \\
\cline { 2 - 11 } & $\mathbf{0}$ & $\mathbf{0 . 1}$ & $\mathbf{0 . 2}$ & $\mathbf{0 . 3}$ & $\mathbf{0 . 4}$ & $\mathbf{0 . 5}$ & $\mathbf{0 . 6}$ & $\mathbf{0 . 7}$ & $\mathbf{0 . 8}$ & $\mathbf{0 . 9}$ & $\mathbf{1}$ \\
\hline Baemin & 0.4053 & 0.4063 & 0.4073 & 0.4083 & 0.4094 & 0.4104 & 0.4114 & 0.4124 & 0.4134 & 0.4144 & 0.4154 \\
Foody & 0.6371 & 0.6497 & 0.6622 & 0.6748 & 0.6874 & 0.7000 & 0.7126 & 0.7252 & 0.7378 & 0.7504 & 0.7630 \\
GoFood & 0.4570 & 0.4589 & 0.4608 & 0.4628 & 0.4647 & 0.4667 & 0.4686 & 0.4705 & 0.4725 & 0.4744 & 0.4764 \\
GrabFood & 0.5517 & 0.5618 & 0.5719 & 0.5821 & 0.5922 & 0.6023 & 0.6125 & 0.6226 & 0.6327 & 0.6429 & 0.6530 \\
Loship & 0.2814 & 0.2933 & 0.3052 & 0.3171 & 0.3290 & 0.3410 & 0.3529 & 0.3648 & 0.3767 & 0.3886 & 0.4006 \\
Now & 0.5152 & 0.5206 & 0.5260 & 0.5313 & 0.5367 & 0.5421 & 0.5474 & 0.5528 & 0.5582 & 0.5635 & 0.5689 \\
\hline
\end{tabular}

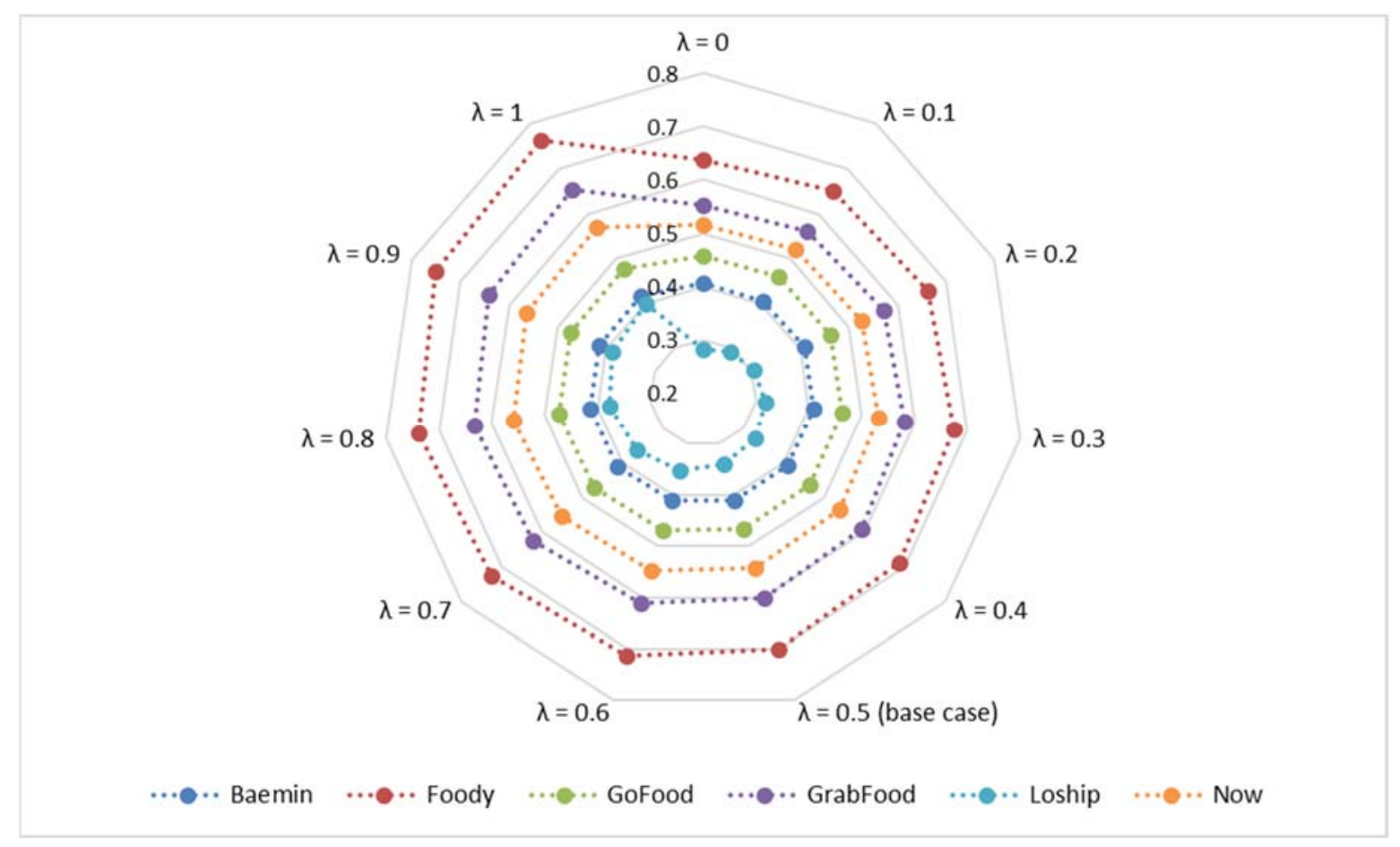

Figure 6. The sensitivity analysis to change in the trade-off parameter $\lambda$.

\section{Discussions}

In the presented research work, a hybrid MCDM framework for the assessment of the OFD market in Vietnam is established concerning a comprehensive set of criteria: social and environmental dimensions (healthy and safety, information security, and environmental impact), economic aspects (delivery cost, operational capability, and risk management), service quality (order fulfillment, delivery speed, convenience of payment, online/offline service level, and customer feedback), and technology (web design, real-time tracking systems, and marketing techniques). In view of the discussion by exhaustively reviewing the literature, the combination of FAHP and WASPAS has been proposed for the first time in the current research to solve the problem. By using the triangular fuzzy sets in the AHP, experts' judgments in linguistic terms can be translated to obtain more scientific and accurate attribute weights of the criteria. Moreover, the consistency test was performed to check the uniformity of the expert's input while the sensitivity analysis was implemented to test the robustness of the approach. With the presented case study being successfully addressed, the trustworthiness of the proposed integrated framework is demonstrated. The results illustrate that the applied model reach common green OFD company rankings.

From the FAHP findings, three criteria of the service quality aspect (convenience of payment, delivery speed, online service level, order fulfillment) and one criterion of the economic factor (delivery cost) have been ranked as the topmost OFD evaluation criteria. 
From Figure 4, it is noteworthy to look at the "convenience of payment" criterion which obtains a dominant weight. In Vietnam, the convenience of payment for online shopping is extremely essential to fulfill the customer's need in the first place. While the benefits of cashless payment such as credit or internet banking have been proven, reducing costs and bringing many conveniences to customers and businesses, a vast majority of Vietnamese still prefer cash-on-delivery payment over online transactions [50], compared to many other countries. The reason is due to the Vietnamese shopping behaviors, and the experience of not using cash is still inconvenient in this country. Thus, not only businesses especially those in e-commerce but also the Vietnamese government have faced an uphill task to encourage cashless payments, that is creating a sustainable digital payments market that is easy for people to use [51]. From other perspectives, it is an exceptional competitive advantage for the OFD companies to devise cutting-edge technology solutions that promise more effective order fulfillment while saving time and reducing costs. Merging orders, multi-delivery options via robots and drones, and cloud kitchens are among trends for OFD businesses to stay afloat and win customers [52].

From the final ranking by WASPAS analysis, the best performing OFD company in today's OFD market in Vietnam with respect to the selected evaluation criteria is Foody (0.7), followed by GrabFood (0.6023), Now (0.5421), GoFood (0.4667), Baemin (0.4104), and Loship (0.3410), according to Figure 5. The obtained results can be utilized as a guideline for the OFD managers and decision-makers to assess their businesses by considering broader aspects and determining major determinants in the industry. All selected evaluation criteria in the current study will help OFD businesses to handle numerous challenges and encourage them to look at the efforts of sustainable development. While several aspects such as service quality, economic factors, and technology have been focused on in the OFD market assessment in Vietnam and other markets, bearing in mind social and environmental subjects still remains a challenge.

\section{Conclusions and Future Works}

The potential of the food delivery industry is endless and the OFD services are becoming an indispensable part of people's day-to-day lives. The OFD businesses are fast catching up across markets of America, Asia, Europe, and the Middle East. In Vietnam, six foremost players in the OFD industry, namely Baemin, Foody, GoFood, GrabFood, Loship, and Now, are taking over the major market share. Even though there is a bright future with numerous possibilities for these current players, in particular, and those entrepreneurs planning to start their OFD businesses, this sector has a competitive landscape. Thus, it is essential for the OFD businesses to take a number of measures and relevant aspects into consideration for the sake of sustainable development in this competing market.

The main contributions of this paper can be summarized as follows. First, the comprehensive development of the OFD market assessment criteria employing industry expert's responses and literature is the significant advantage of this research. Second, to the best of the authors' knowledge, none of the existing studies presented a case study of assessing the OFD companies in Vietnam using the proposed framework (i.e., FAHP and WASPAS). The applied sensitivity analysis will allow the decision-makers to test the observation stability. Finally, the managerial implications of the applied methodology and its analysis will provide insight to decision-makers of the OFD industry not only in Vietnam but also in the global market. For future studies, the proposed method in this paper can be associated with more novel factors that affect the market. Methodologically, different MCDM techniques such as TOPSIS, VIKOR, PROMETHEE, DEA, and combinations of them could be utilized [53,54]. Further research could also apply the proposed method or relevant approaches to specific cases of industries especially those relating to e-commerce to test the general validity of the results. 
Author Contributions: Conceptualization, N.B.T.N. and G.-H.L.; Data curation, N.B.T.N.; Formal analysis, N.B.T.N.; Investigation, G.-H.L.; Methodology, N.B.T.N. and T.-T.D.; Project administration, G.-H.L.; Software, N.B.T.N.; Validation, G.-H.L.; Writing-original draft, N.B.T.N. and T.-T.D.; Writingreview and editing, G.-H.L. and N.B.T.N. All authors have read and agreed to the published version of the manuscript.

Funding: This research received no external funding.

Institutional Review Board Statement: Not applicable.

Informed Consent Statement: Not applicable.

Data Availability Statement: Not applicable.

Acknowledgments: The authors appreciate the support from the National Kaohsiung University of Science and Technology, Taiwan; and Da Lat University, Vietnam.

Conflicts of Interest: The authors declare no conflict of interest.

\section{Appendix A}

Table A1. The integrated fuzzy comparison matrix (FAHP model).

\begin{tabular}{|c|c|c|c|c|c|c|c|c|c|c|c|c|}
\hline \multirow{2}{*}{$\begin{array}{c}\text { Criteria } \\
\text { C11 }\end{array}$} & \multicolumn{3}{|c|}{ C11 } & \multicolumn{3}{|c|}{$\mathrm{C} 12$} & \multicolumn{3}{|c|}{ C13 } & \multicolumn{3}{|c|}{ C21 } \\
\hline & 1.0000 & 1.0000 & 1.0000 & 1.4142 & 2.1822 & 3.1408 & 0.6481 & 1.0699 & 1.8171 & 0.3816 & 0.5888 & 1.0699 \\
\hline $\mathrm{C} 12$ & 0.3184 & 0.4582 & 0.7071 & 1.0000 & 1.0000 & 1.0000 & 0.6177 & 1.0000 & 1.6189 & 0.6177 & 1.0000 & 1.6189 \\
\hline $\mathrm{C} 13$ & 0.5503 & 0.9347 & 1.5431 & 0.6177 & 1.0000 & 1.6189 & 1.0000 & 1.0000 & 1.0000 & 1.1776 & 1.9442 & 2.8845 \\
\hline $\mathrm{C} 21$ & 0.9347 & 1.6984 & 2.6207 & 0.6177 & 1.0000 & 1.6189 & 0.3467 & 0.5144 & 0.8492 & 1.0000 & 1.0000 & 1.0000 \\
\hline $\mathrm{C} 22$ & 0.4368 & 0.6934 & 1.1447 & 0.6177 & 1.0000 & 1.6189 & 0.6177 & 1.0000 & 1.6189 & 0.2887 & 0.4082 & 0.7071 \\
\hline $\mathrm{C} 23$ & 0.3504 & 0.5246 & 0.8909 & 0.4903 & 0.7418 & 1.2009 & 0.4368 & 0.6934 & 1.1447 & 0.3637 & 0.5503 & 0.9532 \\
\hline $\mathrm{C} 24$ & 0.3504 & 0.5246 & 0.8909 & 0.4903 & 0.7418 & 1.2009 & 0.4368 & 0.6934 & 1.1447 & 0.3637 & 0.5503 & 0.9532 \\
\hline $\mathrm{C} 25$ & 0.4582 & 0.7418 & 1.2849 & 0.6177 & 1.0000 & 1.6189 & 1.5131 & 2.5698 & 3.5954 & 2.0396 & 3.0862 & 4.1071 \\
\hline $\mathrm{C} 26$ & 1.0491 & 1.8171 & 2.7495 & 0.8492 & 1.3218 & 1.8860 & 0.6813 & 0.9532 & 1.3218 & 0.4582 & 0.7418 & 1.2849 \\
\hline C31 & 0.4011 & 0.6177 & 0.9532 & 1.0491 & 1.8171 & 2.7495 & 0.9806 & 1.5431 & 2.4019 & 0.4582 & 0.7418 & 1.2849 \\
\hline C32 & 0.8327 & 1.3480 & 2.0396 & 0.2623 & 0.3566 & 0.5612 & 0.6813 & 0.9532 & 1.3218 & 0.4582 & 0.7418 & 1.2849 \\
\hline C33 & 0.4208 & 0.6609 & 1.0699 & 1.0491 & 1.8171 & 2.7495 & 1.5131 & 2.5698 & 3.5 & 1.0 & 1.8171 & 2.7495 \\
\hline C41 & 0.4208 & 0.6609 & 1.0699 & 1.0491 & 1.8171 & 2.7495 & 1.5131 & 2.5698 & 3.5954 & 0.4163 & 0.6481 & 1.0198 \\
\hline $\mathrm{C} 42$ & 0.4208 & 0.6609 & 1.0699 & 0.4163 & 0.6481 & 1.0198 & 1.5131 & 2.5698 & 3.5954 & 0.4163 & 0.6481 & 1.0198 \\
\hline C43 & 0.6609 & 1.0000 & 1.5131 & 0.4163 & 0.6481 & 1.0198 & 0.5612 & 0.8736 & 1.2849 & 0.2887 & 0.4082 & 0.7071 \\
\hline Criteria & \multicolumn{3}{|c|}{$\mathrm{C} 22$} & \multicolumn{3}{|c|}{$\mathrm{C} 23$} & \multicolumn{3}{|c|}{$\mathrm{C} 24$} & \multicolumn{3}{|c|}{$\mathrm{C} 25$} \\
\hline C11 & 0.8736 & 1.4422 & 2.2894 & 1.1225 & 1.9064 & 36 & 1.1225 & 1.9064 & & 0.7783 & 1.3480 & 2.1822 \\
\hline $\mathrm{C} 12$ & 0.6177 & 1.0000 & 1.6189 & 0.8327 & 1.3480 & 2.0396 & 0.8327 & 1.3480 & 2.0396 & 0.6177 & 1.0000 & 1.6189 \\
\hline $\mathrm{C} 13$ & 0.6177 & 1.0000 & 1.6189 & 0.8736 & 1.4422 & 2.2894 & 0.8736 & 1.4422 & 2.2894 & 0.2781 & 0.3891 & 0.6609 \\
\hline $\mathrm{C} 21$ & 1.4142 & 2.4495 & 3.4641 & 1.0491 & 1.8171 & 2.7495 & 1.0491 & 1.8171 & 2.7495 & 0.2435 & 0.3240 & 0.4903 \\
\hline $\mathrm{C} 22$ & 1.0000 & 1.0000 & 1.0000 & 1.0000 & 1.5131 & 2.2209 & 1.0699 & 1.5874 & 2.3051 & 3.2598 & 4.3178 & 5.3527 \\
\hline $\mathrm{C} 23$ & 0.4503 & 0.6609 & 1.0000 & 1.0000 & 1.0000 & 1.0000 & 2.0396 & 3.1408 & 4.1886 & 1.5982 & 2.4495 & 3.4760 \\
\hline $\mathrm{C} 24$ & 0.4338 & 0.6300 & 0.9347 & 0.2387 & 0.3184 & 0.4903 & 1.0000 & 1.0000 & 1.0000 & 3.1072 & 4.1602 & 5.1925 \\
\hline $\mathrm{C} 25$ & 0.1868 & 0.2316 & 0.3068 & 0.2877 & 0.4082 & 0.6257 & 0.1926 & 0.2404 & 0.3218 & 1.0000 & 1.0000 & 1.0000 \\
\hline $\mathrm{C} 26$ & 0.1868 & 0.2316 & 0.3068 & 0.2877 & 0.4082 & 0.6257 & 0.4246 & 0.6000 & 0.7699 & 0.2887 & 0.4082 & 0.7071 \\
\hline C31 & 0.4338 & 0.6300 & 0.9347 & 0.1591 & 0.1895 & 0.2346 & 0.2887 & 0.4149 & 0.6609 & 0.7274 & 1.1447 & 1.9064 \\
\hline C 32 & 0.4724 & 0.7071 & 1.1225 & 0.1591 & 0.1895 & 0.2346 & 0.2451 & 0.3313 & 0.5246 & 0.2887 & 0.4082 & 0.7071 \\
\hline C33 & 1.0000 & 1.6984 & 2.4495 & 0.1550 & 0.1838 & 0.2260 & 0.2451 & 0.3313 & 0.5246 & 0.7274 & 1.1447 & 1.9064 \\
\hline $\mathrm{C} 41$ & 0.3218 & 0.4673 & 0.7418 & 0.1976 & 0.2478 & 0.3340 & 0.2451 & 0.3313 & 0.5246 & 0.2651 & 0.3637 & 0.5888 \\
\hline $\mathrm{C} 42$ & 0.3218 & 0.4673 & 0.7418 & 0.1682 & 0.2027 & 0.2554 & 0.2887 & 0.4149 & 0.6609 & 0.3891 & 0.5503 & 0.8909 \\
\hline $\mathrm{C} 43$ & 0.5888 & 0.9347 & 1.4422 & 0.1640 & 0.1967 & 0.2461 & 0.2887 & 0.4149 & 0.6609 & 1.0491 & 1.6189 & 2.4929 \\
\hline
\end{tabular}


Table A1. Cont.

\begin{tabular}{|c|c|c|c|c|c|c|c|c|c|c|c|c|}
\hline \multirow{2}{*}{$\begin{array}{c}\text { Criteria } \\
\text { C11 }\end{array}$} & \multicolumn{3}{|c|}{$\mathrm{C} 26$} & \multicolumn{3}{|c|}{ C31 } & \multicolumn{3}{|c|}{ C32 } & \multicolumn{3}{|c|}{ C33 } \\
\hline & 0.3637 & 0.5503 & 0.9532 & 1.0491 & 1.6189 & 2.4929 & 0.4903 & 0.7418 & 1.2009 & 0.9347 & 1.5131 & 2.3762 \\
\hline $\mathrm{C} 12$ & 0.5302 & 0.7565 & 1.1776 & 0.3637 & 0.5503 & 0.9532 & 1.7818 & 2.8040 & 3.8127 & 0.3637 & 0.5503 & 0.9532 \\
\hline $\mathrm{C} 13$ & 0.7565 & 1.0491 & 1.4678 & 0.4163 & 0.6481 & 1.0198 & 0.7565 & 1.0491 & 1.4678 & 0.2781 & 0.3891 & 0.6609 \\
\hline $\mathrm{C} 21$ & 0.7783 & 1.3480 & 2.1822 & 0.7783 & 1.3480 & 2.1822 & 0.7783 & 1.3480 & 2.1822 & 0.3637 & 0.5503 & 0.9532 \\
\hline $\mathrm{C} 22$ & 3.2598 & 4.3178 & 5.3527 & 1.0699 & 1.5874 & 2.3051 & 0.8909 & 1.4142 & 2.1169 & 0.4082 & 0.5888 & 1.0000 \\
\hline $\mathrm{C} 23$ & 1.5982 & 2.4495 & 3.4760 & 4.2628 & 5.2773 & 6.2868 & 4.2628 & 5.2773 & 6.2868 & 4.4243 & 5.4401 & 6.4504 \\
\hline C24 & 1.2988 & 1.6667 & 2.3552 & 1.5131 & 2.4101 & 3.4641 & 1.9064 & 3.0182 & 4.0793 & 1.9064 & 3.0182 & 4.0793 \\
\hline $\mathrm{C} 25$ & 1.4142 & 2.4495 & 3.4641 & 0.5246 & 0.8736 & 1.3747 & 1.4142 & 2.4495 & 3.4641 & 0.5246 & 0.8736 & 1.3747 \\
\hline C26 & 1.0000 & 1.0000 & 1.0000 & 1.1225 & 1.8171 & 2.5698 & 0.4011 & 0.6177 & 0.9532 & 1.1225 & 1.8171 & 2.5698 \\
\hline C31 & 0.3891 & 0.5503 & 0.8909 & 1.0000 & 1.0000 & 1.0000 & 2.1822 & 2.9356 & 3.6199 & 1.0000 & 1.4142 & 1.8860 \\
\hline C32 & 1.0491 & 1.6189 & 2.4929 & 0.2763 & 0.3406 & 0.4582 & 1.0000 & 1.0000 & 1.0000 & 0.2887 & 0.4082 & 0.7071 \\
\hline C33 & 0.3891 & 0.5503 & 0.8909 & 0.5302 & 0.7071 & 1.0000 & 1.4142 & 2.4495 & 3.4641 & 1.0000 & 1.0000 & 1.0000 \\
\hline C41 & 0.3467 & 0.5144 & 0.8492 & 0.2763 & 0.3406 & 0.4582 & 1.0491 & 1.8171 & 2.7495 & 0.6177 & 1.0000 & 1.6189 \\
\hline $\mathrm{C} 42$ & 0.3467 & 0.5144 & 0.8492 & 0.2763 & 0.3406 & 0.4582 & 0.6177 & 1.0000 & 1.6189 & 0.3467 & 0.5144 & 0.8492 \\
\hline $\mathrm{C} 43$ & 0.6177 & 1.0000 & 1.6189 & 0.5302 & 0.7071 & 1.0000 & 0.6177 & 1.0000 & 1.6189 & 0.2435 & 0.3240 & 0.4903 \\
\hline Criteria & & C41 & & & $\mathrm{C} 42$ & & & C43 & & & & \\
\hline C11 & 0.9347 & 1.5131 & 2.3762 & 0.9347 & 1.5131 & 2.3762 & 0.6609 & 1.0000 & 1.5131 & & & \\
\hline $\mathrm{C} 12$ & 0.3637 & 0.5503 & 0.9532 & 0.9806 & 1.5431 & 2.4019 & 0.9806 & 1.5431 & 2.4019 & & & \\
\hline C13 & 0.2781 & 0.3891 & 0.6609 & 0.2781 & 0.3891 & 0.6609 & 0.7783 & 1.1447 & 1.7818 & & & \\
\hline C21 & 0.9806 & 1.5431 & 2.4019 & 0.9806 & 1.5431 & 2.4019 & 1.4142 & 2.4495 & 3.4641 & & & \\
\hline $\mathrm{C} 22$ & 1.3480 & 2.1398 & 3.1072 & 1.3480 & 2.1398 & 3.1072 & 0.6934 & 1.0699 & 1.6984 & & & \\
\hline $\mathrm{C} 23$ & 2.9938 & 4.0357 & 5.0608 & 3.9149 & 4.9324 & 5.9439 & 4.0632 & 5.0846 & 6.0986 & & & \\
\hline $\mathrm{C} 24$ & 1.9064 & 3.0182 & 4.0793 & 1.5131 & 2.4101 & 3.4641 & 1.5131 & 2.4101 & 3.4641 & & & \\
\hline C25 & 1.6984 & 2.7495 & 3.7719 & 1.1225 & 1.8171 & 2.5698 & 0.4011 & 0.6177 & 0.9532 & & & \\
\hline $\mathrm{C} 26$ & 1.1776 & 1.9442 & 2.8845 & 1.1776 & 1.9442 & 2.8845 & 0.6177 & 1.0000 & 1.6189 & & & \\
\hline C31 & 2.1822 & 2.9356 & 3.6199 & 2.1822 & 2.9356 & 3.6199 & 1.0000 & 1.4142 & 1.8860 & & & \\
\hline C32 & 0.3637 & 0.5503 & 0.9532 & 0.6177 & 1.0000 & 1.6189 & 0.6177 & 1.0000 & 1.6189 & & & \\
\hline C33 & 0.6177 & 1.0000 & 1.6189 & 1.1776 & 1.9442 & 2.8845 & 2.0396 & 3.0862 & 4.1071 & & & \\
\hline C41 & 1.0000 & 1.0000 & 1.0000 & 0.2781 & 0.3891 & 0.6609 & 0.6177 & 1.0000 & 1.6189 & & & \\
\hline $\mathrm{C} 42$ & 1.5131 & 2.5698 & 3.5954 & 1.0000 & 1.0000 & 1.0000 & 0.2781 & 0.3891 & 0.6609 & & & \\
\hline $\mathrm{C} 43$ & 0.6177 & 1.0000 & 1.6189 & 1.5131 & 2.5698 & 3.5954 & 1.0000 & 1.0000 & 1.0000 & & & \\
\hline
\end{tabular}

\section{References}

1. Pigatto, G.; Machado, J.G.D.C.F.; dos Santos Negreti, A.; Machado, L.M. Have you chosen your request? Analysis of online food delivery companies in Brazil. Br. Food J. 2017, 119, 639-657. [CrossRef]

2. Cheng, C.C.; Chang, Y.Y.; Chen, C.T. Construction of a service quality scale for the online food delivery industry. Int. J. Hosp. Manag. 2021, 95, 102938. [CrossRef]

3. Four Trends Transforming Online Food Delivery. Available online: https://newsfilter.io/articles/four-trends-transformingonline-food-delivery-what-you-need-to-know-now-1381cd275e509309149000b1305ad432 (accessed on 17 June 2021).

4. Delivery Services a Concern for Eateries. Available online: https://www.arkansasonline.com/news/2020/jun/10/deliveryservices-a-concern-for-eateries/?business (accessed on 17 June 2021).

5. Revenue of Online Food Delivery in Vietnam from 2017 to 2024. Available online: https:/ / www.statista.com/forecasts / 1230463 / revenue-online-food-delivery-vietnam (accessed on 17 June 2021).

6. Vietnam Food Delivery App Bites the Dust. Available online: https://www.theasset.com/article/42323/vietnam-food-deliveryapp-bites-the-dust (accessed on 17 June 2021).

7. Pandemic Pushes up Food-Delivery Apps' Business. Available online: http://hanoitimes.vn/would-baemin-overtake-grabfood-in-vietnam-food-delivery-app-market-315444.html (accessed on 17 June 2021).

8. Li, C.; Mirosa, M.; Bremer, P. Review of Online Food Delivery Platforms and their Impacts on Sustainability. Sustainability 2020, 12, 5528. [CrossRef]

9. Ustali, N.K.; Tosun, N. Bulanık AHP ve Bulanık WASPAS Yöntemleri ile Yeni Ürün Seçimi. Pazarlama İçgörüsü Üzerine Çalışmalar 2019, 3, 25-34.

10. Sergi, D.; Sari, I.U. Prioritization of public services for digitalization using fuzzy Z-AHP and fuzzy Z-WASPAS. Complex Intell. Syst. 2021, 7, 841-856. [CrossRef]

11. Deveci, M.; Canıtez, F.; Gökaşar, I. WASPAS and TOPSIS based interval type-2 fuzzy MCDM method for a selection of a car sharing station. Sustain. Cities Soc. 2018, 41, 777-791. [CrossRef] 
12. Yeo, V.C.S.; Goh, S.K.; Rezaei, S. Consumer experiences, attitude and behavioral intention toward online food delivery (OFD) services. J. Retail. Consum. Serv. 2017, 35, 150-162. [CrossRef]

13. Ghosh, R.; Saha, T.R. A study of E-payment system on food delivery industry: A case study on swiggy. Int. J. Recent Trends Bus. Tour. 2018, 2, 19-25.

14. Gavilan, D.; Balderas-Cejudo, A.; Fernández-Lores, S.; Martinez-Navarro, G. Innovation in online food delivery: Learnings from COVID-19. Int. J. Gastron. Food Sci. 2021, 24, 100330. [CrossRef]

15. Mavi, R.K.; Goh, M.; Zarbakhshnia, N. Sustainable third-party reverse logistic provider selection with fuzzy SWARA and fuzzy MOORA in plastic industry. Int. J. Adv. Manuf. Technol. 2017, 91, 2401-2418. [CrossRef]

16. Halaweh, M. Cash on delivery (COD) as an alternative payment method for e-commerce transactions: Analysis and implications. Int. J. Sociotechnol. Knowl. Dev. 2018, 10, 1-12. [CrossRef]

17. Govindan, K.; Jha, P.C.; Agarwal, V.; Darbari, J.D. Environmental management partner selection for reverse supply chain collaboration: A sustainable approach. J. Environ. Manag. 2019, 236, 784-797. [CrossRef] [PubMed]

18. Dospinescu, N.; Dospinescu, O.; Tatarusanu, M. Analysis of the Influence Factors on the Reputation of Food-Delivery Companies: Evidence from Romania. Sustainability 2020, 12, 4142. [CrossRef]

19. Wang, C. Customer Satisfaction Evaluation of Food Delivery Platforms-Taking Meituan as an Example. In Proceedings of the 2020 International Conference on Big Data Economy and Information Management (BDEIM) 2020, Zhengzhou, China, 11-13 December 2020; pp. 124-127.

20. Gao, T.G.; Huang, M.; Wang, Q.; Wang, X.W. Dynamic organization model of automated negotiation for 3PL providers selection. Inf. Sci. 2020, 531, 139-158. [CrossRef]

21. Wang, C.-N.; Dang, T.-T.; Nguyen, N.-A.-T. Outsourcing Reverse Logistics for E-Commerce Retailers: A Two-Stage Fuzzy Optimization Approach. Axioms 2021, 10, 34. [CrossRef]

22. Ray, A.; Bala, P.K. User generated content for exploring factors affecting intention to use travel and food delivery services. Int. J. Hosp. Manag. 2021, 92, 102730. [CrossRef]

23. Yang, F.X.; Li, X.; Lau, V.M.C.; Zhu, V.Z. To survive or to thrive? China's luxury hotel restaurants entering O2O food delivery platforms amid the COVID-19 crisis. Int. J. Hosp. Manag. 2021, 94, 102855. [CrossRef]

24. $\mathrm{Xu}, \mathrm{X}$. What are customers commenting on, and how is their satisfaction affected? Examining online reviews in the on-demand food service context. Decis. Support Syst. 2021, 142, 113467. [CrossRef]

25. Wang, C.-N.; Nguyen, N.-A.-T.; Dang, T.-T.; Lu, C.-M. A Compromised Decision-Making Approach to Third-Party Logistics Selection in Sustainable Supply Chain Using Fuzzy AHP and Fuzzy VIKOR Methods. Mathematics 2021, 9, 886. [CrossRef]

26. Saaty, T.L. The analytical hierarchy process, planning, priority. In Resource Allocation; RWS Publications: Pittsburgh, PA, USA, 1980.

27. Chen, Z.; Yang, W. An MAGDM based on constrained FAHP and FTOPSIS and its application to supplier selection. Math. Comput. Model. 2011, 54, 2802-2815. [CrossRef]

28. Chen, C.T.; Lin, C.T.; Huang, S.F. A fuzzy approach for supplier evaluation and selection in supply chain management. Int. J. Prod. Econ. 2006, 102, 289-301. [CrossRef]

29. Zarbakhshnia, N.; Wu, Y.; Govindan, K.; Soleimani, H. A novel hybrid multiple attribute decision-making approach for outsourcing sustainable reverse logistics. J. Clean. Prod. 2020, 242, 118461. [CrossRef]

30. Zheng, G.; Zhu, N.; Tian, Z.; Chen, Y.; Sun, B. Application of a trapezoidal fuzzy AHP method for work safety evaluation and early warning rating of hot and humid environments. Saf. Sci. 2012, 50, 228-239. [CrossRef]

31. Lyu, H.M.; Shen, S.L.; Zhou, A.; Yang, J. Risk assessment of mega-city infrastructures related to land subsidence using improved trapezoidal FAHP. Sci. Total Environ. 2020, 717, 135310. [CrossRef]

32. Dutta, B.; Guha, D. Preference programming approach for solving intuitionistic fuzzy AHP. Int. J. Comput. Intell. Syst. 2015, 8 , 977-991. [CrossRef]

33. Onar, S.C.; Oztaysi, B.; Otay, İ.; Kahraman, C. Multi-expert wind energy technology selection using interval-valued intuitionistic fuzzy sets. Energy 2015, 90, 274-285. [CrossRef]

34. Kahraman, C.; Otay, I. Solar PV power plant location selection using a Z-fuzzy number based AHP. Int. J. Anal. Hierarchy Process. 2018, 10, 540. [CrossRef]

35. Kahraman, C.; Öztayşi, B.; Sarı, İ.U.; Turanoğlu, E. Fuzzy analytic hierarchy process with interval type-2 fuzzy sets. Knowl. Based Syst. 2014, 59, 48-57. [CrossRef]

36. Abdullah, L.; Najib, L. A new type-2 fuzzy set of linguistic variables for the fuzzy analytic hierarchy process. Expert Syst. Appl. 2014, 41, 3297-3305. [CrossRef]

37. Gündoğdu, F.K.; Kahraman, C. A novel spherical fuzzy analytic hierarchy process and its renewable energy application. Soft Comput. 2020, 24, 4607-4621. [CrossRef]

38. Liu, P.; Zhu, B.; Wang, P.; Shen, M. An approach based on linguistic spherical fuzzy sets for public evaluation of shared bicycles in China. Eng. Appl. Artif. Intell. 2020, 87, 103295. [CrossRef]

39. Zavadskas, E.K.; Turskis, Z.; Antucheviciene, J.; Zakarevicius, A. Optimization of weighted aggregated sum product assessment. Elektron. Elektrotechnika 2012, 122, 3-6. [CrossRef]

40. Badalpur, M.; Nurbakhsh, E. An application of WASPAS method in risk qualitative analysis: A case study of a road construction project in Iran. Int. J. Constr. Manag. 2019, 1-9. [CrossRef] 
41. Zavadskas, E.K.; Kalibatas, D.; Kalibatiene, D. A multi-attribute assessment using WASPAS for choosing an optimal indoor environment. Arch. Civ. Mech. Eng. 2016, 16, 76-85. [CrossRef]

42. Turskis, Z.; Zavadskas, E.K.; Antucheviciene, J.; Kosareva, N. A hybrid model based on fuzzy AHP and fuzzy WASPAS for construction site selection. Int. J. Comput. Commun. Control. 2015, 10, 113-128. [CrossRef]

43. Alam, K.A.; Ahmed, R.; Butt, F.S.; Kim, S.G.; Ko, K.M. An uncertainty-aware integrated fuzzy AHP-WASPAS model to evaluate public cloud computing services. Procedia Comput. Sci. 2018, 130, 504-509. [CrossRef]

44. Alimohammadlou, M.; Khoshsepehr, Z. Investigating organizational sustainable development through an integrated method of interval-valued intuitionistic fuzzy AHP and WASPAS. Environ. Dev. Sustain. 2021, 1-32.

45. Zadeh, L.A. Fuzzy Sets. Inf. Control 1965, 8, 338-358. [CrossRef]

46. Sun, C.C. A performance evaluation model by integrating fuzzy AHP and fuzzy TOPSIS methods. Expert Syst. Appl. 2010, 37, 7745-7754. [CrossRef]

47. Rudnik, K.; Bocewicz, G.; Kucińska-Landwójtowicz, A.; Czabak-Górska, I.D. Ordered fuzzy WASPAS method for selection of improvement projects. Expert Syst. Appl. 2021, 169, 114471. [CrossRef]

48. Chou, Y.C.; Yen, H.Y.; Dang, V.T.; Sun, C.C. Assessing the Human Resource in Science and Technology for Asian Countries: Application of Fuzzy AHP and Fuzzy TOPSIS. Symmetry 2019, 11, 251. [CrossRef]

49. Buckley, J.J. Ranking Alternatives Using Fuzzy Numbers. Fuzzy Sets Syst. 1985, 15, 21-31. [CrossRef]

50. Vietnamese Prefer Offline Payment for Online Shopping. Available online: https://tuoitrenews.vn/news/business/20181017 / vietnamese-prefer-offline-payment-for-online-shopping/47190.html (accessed on 17 June 2021).

51. Vietnam's Payment Preferences: Four Trends to Watch. Available online: https://www.vietnam-briefing.com/news/vietnamspayment-preferences-4-trends-watch.html/ (accessed on 17 June 2021).

52. How to Survive in Competitive Online Food Delivery Business? Available online: https://www.itproportal.com/features/howto-survive-in-competitive-online-food-delivery-business / (accessed on 17 June 2021).

53. Wang, C.-N.; Dang, T.-T.; Nguyen, N.-A.-T.; Le, T.-T.-H. Supporting Better Decision-Making: A Combined Grey Model and Data Envelopment Analysis for Efficiency Evaluation in E-Commerce Marketplaces. Sustainability 2020, 12, 385. [CrossRef]

54. Wang, C.-N.; Dang, T.-T.; Tibo, H.; Duong, D.-H. Assessing Renewable Energy Production Capabilities Using DEA Window and Fuzzy TOPSIS Model. Symmetry 2021, 13, 334. [CrossRef] 